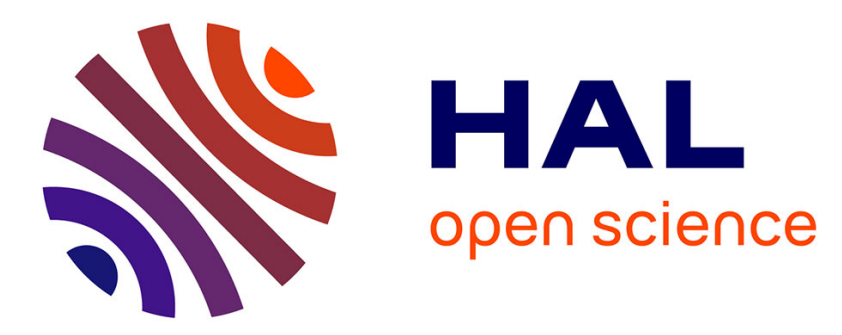

\title{
High resolution array analysis: diagnosing pregnancies with abnormal ultrasound findings
}

Matthew Tyreman, Kristin M Abbott, Lionel R Willatt, Richard Nash, Christoph Lees, Joanne Whittaker, Ingrid Simonic

\section{To cite this version:}

Matthew Tyreman, Kristin M Abbott, Lionel R Willatt, Richard Nash, Christoph Lees, et al.. High resolution array analysis: diagnosing pregnancies with abnormal ultrasound findings. Journal of Medical Genetics, 2009, 46 (8), pp.531. 10.1136/jmg.2008.065482 . hal-00552687

\section{HAL Id: hal-00552687 \\ https://hal.science/hal-00552687}

Submitted on 6 Jan 2011

HAL is a multi-disciplinary open access archive for the deposit and dissemination of scientific research documents, whether they are published or not. The documents may come from teaching and research institutions in France or abroad, or from public or private research centers.
L'archive ouverte pluridisciplinaire HAL, est destinée au dépôt et à la diffusion de documents scientifiques de niveau recherche, publiés ou non, émanant des établissements d'enseignement et de recherche français ou étrangers, des laboratoires publics ou privés. 


\section{Title}

High resolution array analysis: diagnosing pregnancies with abnormal ultrasound findings

\section{Authors/Affiliations}

Matthew Tyreman, ${ }^{1}$ Kristin M. Abbott, ${ }^{1}$ Lionel R. Willatt, ${ }^{1}$ Richard Nash, ${ }^{1}$ Christoph

Lees, ${ }^{2}$ Joanne Whittaker ${ }^{1}$, Ingrid Simonic ${ }^{1}$

${ }^{1}$ Medical Genetics Department, Addenbrooke's Hospital, Cambridge CB2 0QQ, UK.

${ }^{2}$ Fetal Medicine Department, Addenbrooke's Hospital, Cambridge CB2 0QQ, UK

Correspondence to: Dr Ingrid Simonic, Medical Genetics Department, Addenbrooke's Hospital, Cambridge CB2 0QQ, UK

Telephone: $+44(0) 1223348771$

Fax: +44 (0)1223 348712

e-mail: ingrid.simonic@addenbrookes.nhs.uk

Key Words: microarray analysis, prenatal diagnosis, ultrasonography

Word Count: 4,850 


\section{ABSTRACT}

Background: Genome-wide high resolution array analysis is becoming established as a diagnostic test in the investigation of individuals with learning disability and congenital anomalies; many novel microdeletion and microduplication syndromes have already been identified. The diagnostic use of high resolution array genomic hybridisation analysis for prenatal testing remains to be systematically assessed.

Methods: We studied 106 prenatal samples with abnormal ultrasound and a normal karyotype using the Affymetrix GeneChip 6.0 array. 'Rare' DNA copy number changes (CNVs) were classified into three groups depending on their size, genomic location and the presence or absence of matched copy number changes in a large cohort of 3,000 control samples analysed for copy number changes using genotyping arrays.

Results: A total of 35 rare CNVs were identified. 10 (9\%) of these are considered likely to represent pathogenic CNVs; 5 were syndromic and 5 were novel. 12 CNVs were detected in at least one control hybridisation and likely to be benign, and 13 CNVs were of unknown clinical significance. In addition, we identified one case of cryptic mosaicism for trisomy 10 , one case of loss of heterozygosity ( $\mathrm{LOH}$ ) and showed that the Affymetrix GeneChip 6.0 array platform can detect triploidy.

Conclusions: We conclude that careful implementation of high resolution array testing would benefit at least $10 \%$ of obstetric patients with abnormal ultrasound findings and a normal karyotype result.

\section{Key Words}

microarray analysis, prenatal diagnosis, ultrasonography 


\section{INTRODUCTION}

Routine prenatal ultrasound scanning in the first and second trimesters has become an integral component of antenatal care around the world. Detection of major fetal abnormalities can inform pregnancy management. In most instances, the decisions regarding further management of affected pregnancies are undertaken in conjunction with other diagnostic tests. One fifth of abnormal ultrasound cases will have a significant cytogenetics anomaly found, which will inform the parents and clinicians of subsequent morbidity and mortality[1,2]. However, in a significant proportion of such pregnancies decisions have to be made without knowing the aetiology.

In postnatal cytogenetics of individuals with learning difficulties and congenital abnormalities, genome-wide microarray analysis has become an adjunct to karyotyping. This has increased the detection rate of submicroscopic pathogenic copy number changes associated with learning difficulties and congenital abnormalities by as much as $10-15 \%$. A number of new submicroscopic copy number change syndromes have been identified[3-8]. We asked if a similar increase in diagnoses may be achieved in pregnancies with abnormal ultrasound findings were microarray testing to be implemented.

We have performed a retrospective analysis on 106 karyotypically normal referrals with abnormal ultrasound findings using the GeneChip 6.0 array from Affymetrix. This array platform provides uniquely high resolution coverage of the genome with over 1.8 million probes, using oligonucleotide targets that provide copy number information only and single nucleotide polymorphisms (SNPs) oligonucleotide targets which provide genotyping as well as copy number information. Genome-wide screening using this platform was expected to detect all known syndromes that result from copy number changes as well as new ones and to 
provide additional genotyping information including the detection of loss of heterozygosity $(\mathrm{LOH})$.

To deal with the interpretational challenge associated with higher density microarrays we used careful assessment of copy number changes observed in large publicly available datasets of normal individuals.

\section{MATERIALS AND METHODS}

\section{Samples}

All samples used in this study were referred for diagnostic cytogenetic analysis because of major ultrasound abnormalities or multiple soft markers detected by standard 2D ultrasonography. As part of the prenatal diagnostic work-up, all samples were cultured and karyotyped. The surplus cultured material from samples with normal G-banded karyotype analysis (450-550 banding resolution) and 22q11.2 FISH was frozen and stored in liquid nitrogen as part of the diagnostic management of the patient. DNA and additional cytogenetic slides were prepared from 106 retrospective, randomly selected, successfully reconstituted anonymised samples stored between 2001 and 2007. An abnormal triploid $(69, \mathrm{XXY})$ sample was also analysed to assess the allelic difference algorithm of the analysis software for detection of triploidy.

Of the 106 samples included in the study, 87 were second and third trimester amniotic fluid samples, 15 were referred as first trimester chorionic villus (CV) biopsies, and 4 samples were post-termination placental biopsies. All samples were linked to detailed clinical information available at the time of referral for chromosome analysis. The referral categories included 34 samples for congenital heart abnormalities, 24 samples for multisystem abnormalities and multiple soft markers, 
18 samples were referred for very large nuchal mass, cystic hygroma or hydrops fetalis, 16 samples for brain abnormalities including posterior fossa cysts, ventriculomegaly, agenesis of corpus callosum, 6 samples were referred for skeletal abnormalities or short long bones, 2 samples for isolated abdominal wall defects, and 6 samples were referred for other abnormalities.

A constraint of the ethical approval for this study was that there is no followup data on these cases as some may be identifiable, so only the clinical referral information can be linked to the results.

This anonymised study was approved by the Cambridgeshire 1 Research Ethics Committee and the Research and Development Review Board at the Cambridge University NHS Foundation Trust.

\section{GeneChip 6.0 (Affymetrix) array hybridization}

DNA was extracted from cells using Qiagen's DNeasy Blood and Tissue kit following the manufactures instructions. RNase treatment was performed to remove the high levels of RNA in these cell types. DNA concentration and purity $\left(\mathrm{A}_{260-280} \sim 1.8-2.0\right)$ was determined using a NanoDrop ${ }^{\mathrm{TM}}$ spectrophotometer (Thermo Fisher Scientific Inc., USA). Samples (20 $\mu$ l) diluted to $\sim 100 \mathrm{ng} / \mu \mathrm{l}$ were sent to Almac Diagnostics for further processing and hybridization to Affymetrix GeneChip 6.0 array (see Affymetrix Genomewide Human SNP Nsp/Sty 6.0 User Guide for details).

\section{GeneChip 6.0 data analysis (see Affymetrix Genotyping Console 2.1 user manual for details)}

The .CEL intensity files were loaded into Genotyping Console v2.1 (Affymetrix UK Ltd.) for analysis. All samples passed the initial contrast QC metric (>0.4) that 
measures the ability of the intensity files to resolve SNPs into three genotyping clusters.

Copy number data were generated by comparing intensities for both SNP and copy number probes 'in silico' to the HapMap control provided by Affymetrix. The resulting $\log _{2}$ ratios were then analysed using a Hidden Markov Model (HMM) to generate copy number calls for each probe.

The quality of the $\log _{2}$ data was assessed by the degree of variation, determined by the MAPD metric. MAPD is defined as the Median of the Absolute value of all Pairwise Differences between $\log _{2}$ ratios for a given chip. High MAPD, $>0.4$ (using the HapMap control) is considered to be the cut-off at which copy numbers can no longer be accurately called. None of the samples included in this study had a MAPD >0.4.

Using the copy number calls provided by Genotyping Console v2.1 as a guide, a more detailed analysis was performed by interrogation of the plots of $\log _{2}$ ratios paying particular attention to $\mathrm{CNV}$ regions called by the HMM. A minimum $\log _{2}$ ratio cut-off of \pm 0.3 was used for autosomal CNVs. This excluded any false positive calls made by the HMM algorithm. Identified CNVs were checked against the Database of Genomic Variants (DGV) and gene tracks in Genotyping Console v2.1. CNVs were excluded from further analysis if they matched a known CNV exactly[9-12], matched no known CNV but fell outside gene boundaries, occurred in a known variable region but have not previously been reported as pathogenic CNVs (particularly within pericentromeric and subtelomeric polymorphic loci)[13], and finally if they significantly overlapped with polymorphic CNVs identified by McCarroll et al.[14] on the same array platform (see supplementary fig 1 for examples). CNVs 
incorporating at least 25 probes and not identified as a known $\mathrm{CNV}$ were considered rare and recorded for further investigation.

The allelic difference and loss of heterozygosity plots generated from the difference in allele intensity for each SNP were analysed to investigate parental consanguinity and as an aid to the interpretation of potential mosaicism. Genotyping was performed using the Birdseed v.2 algorithm. All samples had call rates greater than $97.5 \%$.

\section{FISH and Q-PCR}

Large deletions and duplications were confirmed with FISH using standard cytogenetic laboratory techniques and BAC clones from the 30K TPA clones set. $5 \mu 1$ of probe (approx $0.5 \mu \mathrm{g}$ DNA) was labelled with either Spectrum Orange or Green dUTP (Abbott Molecular UK), using Nick Translation Kit reagents (Abbott Molecular UK), and re-suspended in $4 \mu \mathrm{l}$ TE buffer. $1 \mu \mathrm{l}$ of probe was used per slide with $1 \mu \mathrm{l}$ Cot1 and $8 \mu$ l Hybridisation buffer (Hybrisol VII). Slides washed and counter stained with DAPI were analyzed using fluorescence microscopy (Olympus BX61, UK), and images recorded using SmartCapture 3 software (Digital Scientific, UK).

Small deletions (<100 kb) and duplications $(<1.5 \mathrm{Mb})$ were confirmed by QPCR using GAPDH as a reference gene. Each Q-PCR reaction $(20 \mu \mathrm{l})$ contained $10 \mu \mathrm{l}$ POWER SYBR Green (2x) master mix (Applied Biosystems, USA), primers for the control gene $(\mathrm{GAPDH})$ or gene of interest $(0.3 \mu \mathrm{M}), \sim 100 \mathrm{ng}$ template DNA and DNase free water. Q-PCR was performed using Corbett Life Science's Rotor-Gene 6000 software (Australia) and standard Q-PCR cycling conditions: $10 \mathrm{mins}$ at $95^{\circ} \mathrm{C}$, then 35 cycles of $15 \mathrm{~s}$ at $95^{\circ} \mathrm{C}, 30 \mathrm{~s}$ at $60^{\circ} \mathrm{C}$ and $30 \mathrm{~s}$ at $72^{\circ} \mathrm{C}$. Finally a product melt was performed by ramping the temperature back to $95^{\circ} \mathrm{C}$. 


\section{RNA extraction and two step RT-qPCR}

RNA was extracted from cultured cells using Qiagen's RNeasy isolation kit. Purified RNA was either stored at $-20^{\circ} \mathrm{C}$ or used immediately as a template for total RNA RTPCR using Qiagen's QuantiTect reverse transcription kit following the manufacturer's instructions. The level of expression was quantified using quantitative RT-PCR (as described above for Q-PCR) using cDNA specific primers.

\section{Welcome Trust Case Control Consortium (WTCCC) sample analysis}

The WTCCC samples consist of 1500 cell lines from the 1958 Birth Cohort and 1500 DNA samples from the UK national repository of anonymised blood donor samples[15]. The 1958 Birth Cohort (or National Child Development Study) included all births in England, Scotland and Wales occurring within one week in March 1958. All samples used for the WTCCC were acquired during a follow-up consultation at the age of 44-45 years. The 1500 samples are representative of both genders and each geographical region. The National Blood Service samples included consenting

participants from England, Scotland and Wales between 18-69 years. 1500 samples of similar gender and geographical distribution to the Birth Cohort samples were selected for the WTCCC.

The intensity files for the 3000 individuals were applied for and acquired from the Wellcome Trust Sanger Institute and used to examine the occurrence of 'rare' CNVs within a 'normal' population.

The GeneChip 250K_Nsp array data generated by the WTCCC for the 3000 control samples was analyzed using Genotyping Console v2.0 (GTC). A sex-matched copy number analysis was performed using HapMap controls. NEXUS software 
(BioDiscovery Inc., USA) was used to display multiple copy number files created by GTC using stringent parameters suggested by the manufacturer.

\section{RESULTS}

In total, 35 DNA copy number changes (30 novel and 5 previously reported pathogenic CNVs) were identified for further analysis, 2 of these were found in two and 1 in three samples. Based on the size, gene content, previously reported cases in the literature and the presence or absence of matched CNVs in control samples (WTCCC and unaffected individuals identified in our laboratory in the course of a postnatal diagnostic follow-up), these rare CNVs were classified into three groups and are listed in tables 1-3.

\section{Likely pathogenic rare $C N V s$}

Ten of the 35 rare CNVs were considered to be likely pathogenic (table 1, figs 1 and 2, supplemental fig 3). None of these CNVs were found in the $3000 \mathrm{WTCCC}$ control samples or in the other unaffected individuals identified in our laboratory.

Four of the CNVs overlapped with previously published pathogenic microdeletions. A deletion $(\sim 0.5 \mathrm{Mb})$ at $17 \mathrm{q} 21.31$ was found in a sample referred due to a large ventricular septal defect (VSD). The 17q21.31 microdeletion syndrome is mainly characterised by hypotonia, dysmorphic facial appearance and developmental delay, with heart defects being less common features[3-5]. Two deletions were detected within $22 \mathrm{q} 11.2$. The first ( $750 \mathrm{~kb}$ in size $)$ was in a sample referred for a heart defect and was nested within the typical $3 \mathrm{Mb} 22 \mathrm{q} 11.2$ microdeletion but did not include the DiGeorge critical region. Similar distal deletions have previously been reported with cardiac anomalies[16-18]. The second of the 22q11.2 deletions was an 
Table 1. Likely Pathogenic CNVs

\begin{tabular}{ccccrcrrr}
\hline $\begin{array}{c}\text { Copy } \\
\text { No. }\end{array}$ & $\begin{array}{c}\text { Loss/ } \\
\text { Gain }\end{array}$ & Chr & Cytoband & $\begin{array}{r}\text { Size } \\
(\mathrm{kb})\end{array}$ & $\begin{array}{c}\text { Start } \\
\text { Position* }\end{array}$ & $\begin{array}{c}\text { End } \\
\text { Position* }\end{array}$ & Start Marker & End Marker \\
\hline 3 & Gain & 15 & $\mathrm{q} 21.1 \mathrm{q} 21.1$ & 729 & 42831204 & 43559740 & SNP_A-8345787 & SNP_A-1859646 \\
1 & Loss & 15 & $\mathrm{q} 26.2 \mathrm{q} 26.2$ & 3571 & 92557725 & 96128332 & CN_725893 & SNP_A-8374247 \\
1 & Loss & 16 & $\mathrm{q} 24.1 \mathrm{q} 24.2$ & 1989 & 84286000 & 86275006 & CN_745007 & CN_755946 \\
1 & Loss & 17 & $\mathrm{q} 21.31 \mathrm{q} 21.31$ & 556 & 41014074 & 41569931 & CN_734861 & CN_737156 \\
3 & Gain & 19 & $\mathrm{p} 13.2 \mathrm{p} 13.2$ & 4760 & 7628636 & 12388852 & SNP_A-8539212 & CN_789094 \\
3 & Gain & 19 & $\mathrm{q} 13.41 \mathrm{q} 13.42$ & 529 & 58932027 & 59461178 & CN_796537 & SNP_A-8551967 \\
1 & Loss & 19 & $\mathrm{q} 13.42 \mathrm{q} 13.42$ & 1597 & 59545138 & 61142344 & CN_800868 & SNP_A-8421559 \\
1 & Loss & 22 & $\mathrm{q} 11.21 \mathrm{q} 11.21$ & 749 & 19046924 & 19795835 & CN_900101 & SNP_A-8376166 \\
1 & Loss & 22 & $\mathrm{q} 11.21 \mathrm{q} 11.22$ & 1053 & 20247141 & 21300127 & CN_900338 & CN_873813 \\
0 & Loss & $\mathrm{X}$ & $\mathrm{p} 22.2 \mathrm{p} 22.2$ & 60 & 14743675 & 14803466 & CN_912494 & CN_916888 \\
\hline
\end{tabular}

Table 2. Rare CNVs Identified in Control ${ }^{\ddagger}$ Array Hybridisations

\begin{tabular}{ccclrrrrr}
\hline $\begin{array}{c}\text { Copy } \\
\text { No. }\end{array}$ & $\begin{array}{l}\text { Loss/ } \\
\text { Gain }\end{array}$ & Chr & Cytoband & $\begin{array}{c}\text { Size } \\
(\mathrm{kb})\end{array}$ & $\begin{array}{c}\text { Start } \\
\text { Position* }\end{array}$ & $\begin{array}{c}\text { End } \\
\text { Position* }\end{array}$ & Start Marker & End Marker \\
\hline 3 & Gain & 1 & q21.1q21.1 & 2929 & 144643813 & 147572680 & CN_436401 & CN_005156 \\
3 & Gain & 2 & p12p12 & 151 & 79992846 & 80144175 & CN_849251 & CN_849310 \\
3 & Gain & 2 & q14.3q14.3 & 183 & 127635670 & 127818407 & CN_814671 & CN_814739 \\
3 & Gain & 2 & q24.1q24.2 & 305 & 159351110 & 159656347 & CN_815439 & SNP_A-1906806 \\
1 & Loss & 4 & q21.3q21.3 & 168 & 87712551 & 87880721 & CN_1098901 & CN_1098950 \\
1 & Loss & 6 & p22.1p22.1 & 71 & 26488457 & 26559532 & SNP_A-8672948 & SNP_A-2107841 \\
1 & Loss & 7 & q34q34 & 64 & 142538076 & 142601831 & SNP_A-8504569 & CN_1195107 \\
1 & Loss & 17 & p13.1p13.1 & 53 & 10175316 & 10228548 & SNP_A-8316868 & SNP_A-4259604 \\
3 & Gain & 18 & p11.31p11.23 & 255 & 7034693 & 7289938 & SNP_A-8659367 & CN_162287 \\
3 & Gain & $X$ & p11.3p11.3 & 735 & 42658326 & 43393758 & CN_975615 & CN_944209 \\
3 & Gain & $X$ & q22.3q22.3 & 535 & 105020902 & 105555463 & CN_915981 & SNP_A-4272644 \\
3 & Gain & $X$ & q27.3q27.3 & 284 & 142191812 & 142476144 & CN_923443 & CN_925603 \\
\hline
\end{tabular}

Table 3. Rare CNVs Not Identified in Control ${ }^{\ddagger}$ Array Hybridisations

\begin{tabular}{ccclrrrrr}
\hline $\begin{array}{c}\text { Copy } \\
\text { No. }\end{array}$ & $\begin{array}{c}\text { Loss/ } \\
\text { Gain }\end{array}$ & Chr & Cytoband & $\begin{array}{c}\text { Size } \\
(\mathrm{kb})\end{array}$ & \multicolumn{1}{c}{$\begin{array}{c}\text { Start } \\
\text { Position }^{*}\end{array}$} & $\begin{array}{c}\text { End } \\
\text { Position }^{*}\end{array}$ & \multicolumn{1}{c}{ Start Marker } & \multicolumn{1}{c}{ End Marker } \\
\hline 3 & Gain & 2 & $\mathrm{q} 11.2 \mathrm{q} 11.2$ & 136 & 100885342 & 101021754 & SNP_A-8363841 & CN_781396 \\
1 & Loss & 3 & $\mathrm{p} 26.2 \mathrm{p} 26.2$ & 191 & 4465777 & 4656908 & CN_1019660 & SNP_A-2215036 \\
1 & Loss & 4 & $\mathrm{q} 13.1 \mathrm{q} 13.1$ & 73 & 62018599 & 62091738 & CN_1074069 & CN_1074096 \\
1 & Loss & 8 & $\mathrm{q} 21.11 \mathrm{q} 21.11$ & 442 & 77982322 & 78424626 & SNP_A-1852526 & CN_1277827 \\
1 & Loss & 8 & $\mathrm{q} 22.2 \mathrm{q} 22.2$ & 50 & 99614669 & 99664963 & CN_1327739 & CN_1327758 \\
3 & Gain & 9 & $\mathrm{p} 24.3 \mathrm{p} 24.3$ & 198 & 336739 & 534519 & SNP_A-4267299 & SNP_A-8435185 \\
3 & Gain & 12 & $\mathrm{q} 14.1 \mathrm{q} 14.1$ & 1238 & 59716019 & 60954182 & SNP_A-8393568 & CN_622744 \\
3 & Gain & 13 & $\mathrm{q} 12.3 \mathrm{q} 12.3$ & 241 & 29263783 & 29505076 & SNP_A-8427957 & SNP_A-1875934 \\
1 & Loss & 13 & $\mathrm{q} 21.2 \mathrm{q} 21.2$ & 85 & 59445984 & 59530649 & CN_632878 & CN_632907 \\
4 & Gain & 15 & $\mathrm{q} 21.1 \mathrm{q} 21.1$ & 94 & 43705221 & 43799561 & CN_691975 & SNP_A-8689230 \\
3 & Gain & 16 & $\mathrm{p} 13.2 \mathrm{p} 13.2$ & 175 & 8769713 & 8944958 & SNP_A-8328707 & CN_732050 \\
3 & Gain & $\mathrm{X}$ & $\mathrm{p} 22.12 \mathrm{p} 22.12$ & 392 & 19470418 & 19862134 & CN_914967 & CN_917170 \\
1 & Loss & $\mathrm{X}$ & $\mathrm{q} 24 \mathrm{q} 24$ & 90 & 118239441 & 118329782 & SNP_A-8450878 & CN_922882 \\
\end{tabular}

* Physical positions utilize the hg17(b36) build of the human genome sequence

₹ WTCCC and unaffected parents identified in our laboratory 
approximately $1 \mathrm{Mb}$ deletion extending from $22 \mathrm{q} 11.21$ to $22 \mathrm{q} 11.22$ found in a sample referred for multiple VSDs and hypospadias. This deletion is consistent with 22q11.2 distal deletion syndrome[6] and a patient with multiple VSDs and a clinical diagnosis of Goldenhar syndrome has been reported previously with an overlapping deletion of similar size[19]. The fourth case was a deletion of $\sim 3.5 \mathrm{Mb}$ at $15 \mathrm{q} 26.2$ detected in a sample referred for hypoplastic left heart. Deletions of this region have been described with congenital diaphragmatic hernia $(\mathrm{CDH})$, congenital heart disease, and kidney defects[20, 21]. It is interesting that the deletion incorporates the NR2F2 gene (MIM*107773) reported to be involved in angiogenesis and heart development[22]. Although $\mathrm{CDH}$ was not identified by ultrasound in this case, $\mathrm{CDH}$ is detected prenatally in only about $60 \%$ of patients and heart 'hypoplasia' is among anomalies frequently found in association with $\mathrm{CDH}[23]$.

The smallest pathogenic CNV identified was a $60 \mathrm{~kb}$ deletion at $\mathrm{Xp} 22.2$ detected in a placental biopsy of a male fetus with hydrocephalus, cleft lip and palate, absent radii, short forearms, and intestinal atresia. The deletion incorporated the entire FANCB gene (MIM*300515) gene. The ultrasound abnormalities and the absence of FANCB gene in the fetus are consistent with the clinical diagnosis of Fanconi anaemia and X-linked VACTERL association with hydrocephalus (MIM\#314390)[24].

There were 5 other novel CNVs that were considered to be likely pathogenic. A deletion of $\sim 2 \mathrm{Mb}$ within the long arm of chromosome 16 with breakpoints at 16q24.1 and 16q24.2 was detected in a sample referred for hypoplastic left heart and dilated renal pelvices. This deletion encompasses several protein coding genes including cytochrome C oxidase genes COX4NB and COX4I1 (MIM*123864), IRF8 $(\mathrm{MIM} * 601565), \quad$ FOXF1 $\quad(\mathrm{MIM} * 601089), \quad$ FOXC2 $\quad(\mathrm{MIM} * 602402), \quad$ FOXL1 
(MIM*603252), MAPL3b, ZCCHC14, JPH3 (MIM*605268). Haploinsufficiency of the forkhead genes FOXF1 and FOXC2 may be responsible for the heart and renal abnormalities found on prenatal ultrasound in this pregnancy. A duplication of $\sim 730$ $\mathrm{kb}$ within $15 \mathrm{q} 21.1$ was identified in an amniotic fluid sample referred for posterior ventriculomegaly, echogenic intracardiac focus, and echogenic bowel. This involved several genes, namely, SORD (MIM*182500), SHF, DUOX1 (MIM*606758), DUOX2 (MIM*606759), SLC28A2 (MIM*606208), GATM (MIM+602360), SPATA5L1, PLDN (MIM*604310), SLC30A4 (MIM*602095). This case was considered pathogenic because of the size, absence in the WTCCC control samples and no major overlap with CNVs recorded in the DGV. Three abnormalities were identified that involved chromosome 19, a deletion and two duplications, all involving several genes (fig 2). A deletion at 19q13.42 ( 1.6 Mb) was identified in a sample referred for first trimester cystic hygroma. This deletion overlaps with a previously reported significantly larger interstitial duplication with breakpoints at q13.2 and q13.4 in a fetus with cystic hygroma[25]. For the duplications identified, the breakpoints of the duplication at 19p13.2 $(\sim 4.76 \mathrm{Mb})$ in a fetus with cleft lip and palate, renal pyelectasis, and bilateral talipes are similar to the breakpoints reported in DECIPHER for a patient (00001857) with a de novo deletion and multiple congenital abnormalities, suggesting that dosage sensitive genes exist in this region and it may be a site of recurrent pathogenic rearrangement. The $\sim 530 \mathrm{~kb}$ duplication within 19q13.4 identified in a case referred with multiple ultrasound abnormalities including polyhydramnios, micrognathia, abnormal right pinna, absent stomach bubble and given a provisional diagnosis of Treacher Collins syndrome has not been previously reported. 


\section{Rare CNVs identified in control array hybridisations}

Twelve of the rare CNVs were considered likely to be benign in the context of this study. They were identified in one or more WTCCC control samples or were previously identified in our laboratory as being inherited from a normal parent (table 2, supplemental fig 2). It is likely that these CNVs would be inherited and not related to the observed ultrasound abnormalities.

Two CNVs, a deletion mapped to chromosome 7q34 and a duplication mapped to Xq27.3, could not be observed in the WTCCC controls due to the limited resolution of the 250K_Nsp array (i.e., no SNPs) in these genomic regions. Both of these have been previously detected using Affymetrix GeneChip 6.0 array in our laboratory and found to be inherited from a phenotypically normal parent.

All of the other autosomal CNVs and the Xp11.3 apparent duplication were found in at least one control WTCCC hybridisation with similar breakpoints. The $\sim 3$ $\mathrm{Mb}$ duplication within 1q21.1 identified in a sample referred for two soft markers detected on ultrasound (choroid plexus cysts and unilateral renal pyelectasis) has been published previously and has been associated with a mild phenotype in some instances[26, 27]. Similar 1q21.1 duplications were found in three WTCCC control individuals and in a diagnostic setting appropriate counselling could be offered without further family follow-up.

A further apparent duplication of $\sim 535 \mathrm{~kb}$ at Xq22.3 was found in a female sample with multisystem abnormalities detected on ultrasound. A similar duplication was also found in a single female control hybridisation (WTCCC). As a result it was assumed that this CNV does not contribute significantly to the fetal abnormalities in this pregnancy. However, as this duplication has not been observed in a normal male, its pathogenicity can not be fully excluded. 


\section{Rare CNVs of unknown significance}

Thirteen of the 35 rare CNVs identified in this study were novel and not detected in any of the control samples (table 3, fig 3). The sizes of these CNVs ranged from $\sim 50-$ $1238 \mathrm{~kb}$ but their gene content was low (1-3 genes only). In order to determine if these CNVs are of clinical significance further studies including family follow-up would be necessary.

Two rare CNVs on the $\mathrm{X}$ chromosome were detected in a female sample referred for a single umbilical artery and choroid plexus cysts detected on second trimester ultrasound scan. This sample had a duplication $(\sim 392 \mathrm{~kb})$ at Xp22.12 including the SH3KBP1 (MIM*300374) gene and a deletion ( 90 kb) at Xq24 including the PGRMC1 (MIM*300435) gene. The clinical relevance of both these CNVs in the context of a female pregnancy is unknown and further family follow-up would be required in a diagnostic setting.

Two CNVs listed in table 3 included genes known to cause recessive diseases. A deletion $\mathrm{CNV}$ of $\sim 442 \mathrm{~kb}$ on chromosome 8q21.11 contains the PXMP3 gene (MIM+170993). Defects in the function of this gene are known to cause Zellweger syndrome (MIM\#214100). This sample was referred for cystic hygroma at 33 weeks gestation, which could be one of the prenatal features of a peroxisomal disorder[28]. Zellweger syndrome is usually diagnosed postnatally by biochemical testing, which demonstrates abnormally high levels of very long chain fatty acids in the tissues and body fluids. Biochemical testing performed on cultured amniocytes from this sample after long-term storage produced normal levels of very long chain fatty acids indicating that the second allele was functioning normally. 
A deletion of $\sim 191 \mathrm{~kb}$ on chromosome $3 \mathrm{p} 26.2$ has a distal breakpoint in the SUMF1 gene $(M I M * 607939)$ and a proximal breakpoint in the ITPR1 gene (MIM*147265). Biallelic mutations in SUMF1 cause multiple sulfatase deficiency (MIM\#272200), MSD. Partial allelic deletions of SUMF1 and ITPR1 have been described previously[29], as well as large intragenic ITPR1 deletions associated with SCA16[30]. Cytogenetically visible distal 3p deletions have been reviewed recently $[31,32]$ and found to be associated with variable phenotypes. This sample was referred for severe early onset intrauterine growth retardation, posterior fossa cyst, and oligohydramnios. The biochemical test for MSD on this sample failed due to culture fatigue.

An apparent $\sim 198 \mathrm{~kb}$ duplication on chromosome 9p24.3 was detected in an amniotic fluid sample referred for multiple cardiac abnormalities. The CNV appears to disrupt the DOCK8 (MIM+611432) and ANKRD15 genes with the telomeric breakpoint between exons 8-10 in DOCK8 and centromeric breakpoint in the first intron of the ANKRD15 gene. A deletion and translocation involving the DOCK8 gene have been recently reported in two patients with mental retardation and developmental delay[33]. A deletion $(\sim 225 \mathrm{~kb})$ of the ANKRD15 has been reported in a single family with congenital cerebral palsy[34]. There is no known association of either of these genes with cardiac defects. However, the duplication in this sample was confirmed to be in cis (supplemental fig 3) and it would be prudent to consider further familial studies to assess the clinical significance of this $\mathrm{CNV}$ in a diagnostic setting.

Identification of mosaic aneuploidy / LOH / triploidy 
In addition to the 10 cases with likely pathogenic $\mathrm{CNVs}$, one case, a CV with cystic hygroma, was positive for trisomy 10 mosaicism (fig 4) increasing the overall abnormality rate to approximately $10 \%$. It was not possible to investigate the prevalence of trisomy 10 cells in the original diagnostic specimen to exclude cultural artefacts or confined placental mosaicism, however mosaic trisomy10 has been reported previously in a fetus referred for a cystic hygroma[35] and this was therefore considered the likely cause of the ultrasound abnormality.

Using the allelic difference and LOH plots in Genotyping Console v2.1, a single sample was identified with extended LOH tracks on all chromosomes (fig 4). The overall extent of the $\mathrm{LOH}$ was determined to be $\sim 10 \%$ of the autosomal complement. This is similar to that observed in populations where consanguineous marriages occur[36]. This degree of LOH increases the likelihood that the cerebral ventriculomegaly seen on ultrasound in the fetus was caused by an autosomal recessive disease, which are more prevalent in consanguineous populations.

The triploid control sample produced a very distinct allelic difference plot (fig 4). Instead of producing three genotyping clusters, one each for heterozygous $A B$, homozygous AA and BB calls, this triploid sample produced four genotype clusters: $\mathrm{AAA}, \mathrm{AAB}, \mathrm{BBA}$, and $\mathrm{BBB}$. This information is particularly relevant for the future design of diagnostic array platforms aiming to replace rather than complement full karyotype analysis at prenatal diagnosis.

\section{Expression studies}

Several of the CNVs in tables 2 and 3 include a single protein coding gene with no apparent dosage sensitive effects and it is likely that most if not all are inherited from an unaffected parent. To determine if nonsense mutations of the remaining allele lead 
to biallelic inactivation of any of these genes we used real-time quantitative RT-PCR to validate the overall changes in the gene expression and to determine if the nondeleted alleles are targeted for nonsense-mediated decay. We selected four genes, LPHN3 (latrophilin3), PTPN13 (MIM*600267), PXMP3 (MIM+170993), and STK3 (MIM*605030), mapped to deletion CNVs at chromosomes 4q13.1, 4q21.3, 8q21.1, and $8 \mathrm{q} 22.2$, respectively. These genes were expected to be ubiquitously expressed in most tissues without transcription activation treatment. Indeed, all four genes showed similar levels of expression in both controls and the sample carrying the deletion (fig 5) indicating that the transcript from the second allele was stable.

\section{DISCUSSION}

In this consecutive series of pregnancies with abnormal ultrasound findings, 'likely' pathogenic abnormalities were detected in 10\% (11 of 106) of the samples with normal cytogenetics results. Two previous studies on samples with abnormal ultrasound or fetal development have shown detection rates of $1.3 \%(2 / 151)$ and $\sim 10 \%(5 / 49)[37,38]$, but the numbers are small and more studies are needed to determine the true prevalence of cytogenetically undetected, pathogenic DNA copy number changes in prenatal abnormal ultrasound referrals.

We found that single gene deletions/duplications of less than $100 \mathrm{~kb}$ in size could be detected with confidence using the GeneChip 6.0 array (fig 1) and we identified no false positive copy number calls. Furthermore we demonstrated that SNP based targets allow the detection of triploidy and the easy visualisation of mosaic trisomy (fig 4).

In recent reviews of the potential application of microarrays for clinical use in prenatal diagnosis, implementation of targeted arrays has been favoured [39-41]. Our 
study suggests that the design of a prenatal targeted array needs to allow for the fact that prenatal samples referred due to abnormal ultrasound findings have a variety of structural defects under-represented in postnatally ascertained patients and there may be important genomic regions currently overlooked by targeted arrays designed for postnatal testing. Only four of the ten pathogenic CNVs identified in this study involved previously described microdeletion syndromes, and all of these cases had cardiac anomalies and were at the more severe end of the clinical spectrum for these conditions. Three of the novel pathogenic CNVs identified mapped to chromosome 19; two of these were referred for multiple structural fetal abnormalities and one for cystic hygroma, all associated with a significant risk of poor pregnancy outcome. In contrast, interstitial deletions and duplications involving chromosome 19 are rarely detected postnatally[42]. Moreover, since new microdeletion/duplication syndromes continue to be identified on postnatal higher resolution arrays, the coverage of a targeted prenatal array would need to be continually reviewed.

Although, testing for copy number changes using the GeneChip 6.0 array has the advantage that this platform can detect smaller previously undescribed pathogenic CNVs than lower resolution arrays, it was expected that more novel CNVs of unknown significance would be detected. The use of a large control population dataset in this study halved (from 20 to 10) the number of novel CNVs of unknown significance that were initially identified for further investigation. This may reflect the recent suggestion that higher resolution array studies have shown that many of the common CNVs in the DGV are smaller and are less likely to contain significant genes than was originally thought to be the case [14]. With this CNV screening strategy, the proportion of CNVs with unknown clinical significance (table 3) compared with those likely to be pathogenic (table 1) was similar to that in most published series, using 
lower resolution or targeted arrays, in which about half of the rare (non-polymorphic) CNVs detected require parental follow up to help determine their significance[43-46].

Two interpretational issues that would need to be considered before diagnostic prenatal arrays could be applied prospectively were identified in this study. Several previously undescribed copy number changes were identified that included only one or very few genes (table 3). For most of these the relationship, if any, between gene functionality and the ultrasound anomalies is not known. Two of these deletions included known autosomal recessive genes. Biallelic mutations in these genes result in severe phenotypes. Although we tested but failed to confirm defects of the second allele in our two cases, the possibility of detecting recessive disorders that cause abnormal fetal development needs to be borne in mind before implementing prenatal high resolution AGH. In particular, how to rapidly move from sample collection to producing a definitive result within the time-frame required for management of the affected pregnancy. We also found in this study five X chromosome CNVs of no or unknown clinical significance (tables 2 and 3). Although the knowledge about benign DNA copy number variation has increased significantly [14], there is very little known about the variants detected on the $\mathrm{X}$ chromosome and their pathogenic significance in the context of different sexes.

Our study indicates that rare DNA copy number changes are detected in about $30 \%$ of prenatal referrals with either major fetal abnormalities or multiple soft markers when high resolution hybrid arrays are applied. About a third of these rare CNVs are likely to be pathogenic abnormalities (table 1). This finding is similar to the detection rates in postnatal referrals, although the genome-wide distribution of pathogenic CNVs might be different. These additional data would help families to make informed decisions for their pregnancies and generate the recurrence risks for 
future pregnancies. About one third of the detected rare CNVs could be identified in large control population datasets (table 2). These CNVs are therefore likely to be inherited from an unaffected parent and their laboratory follow up would not improve the medical management of the obstetric patients. The detection rate of rare CNVs with unknown clinical significance (table 3 ) in our study was relatively high and it would be prudent to determine their inheritance status in a diagnostic setting. It is likely that for a significant proportion of these it will not be easily possible to interpret their significance. More resources would be required for pre- and post-test counselling for these imbalances that cannot yet be interpreted. The inclusion of such CNVs in public domain CNV databases is vital to determine phenotypes which may otherwise be too complex to model in experimental systems.

At the present time, approximately $70 \%$ of all abnormal ultrasound findings remain without an aetiological diagnosis. Our study suggests that careful implementation of high resolution $\mathrm{AGH}$ analysis to standard practice could significantly improve the diagnostic yield in pregnancies with abnormal ultrasound findings, as well as advance our knowledge of the genetic basis of abnormal fetal development. 
Acknowledgements: The authors wish to thank Dr Matthew Hurles for his advice on CNV analysis and preparation of this manuscript, Dr Geoffrey Woods for his helpful comments, Ms Georgina Parkin for technical support and Dr Carolyn Dunn for expert technical advice regarding quantitative PCR studies. This study was supported by the Biomedical Research Centre Grant from the National Institute for Health Research (NIHR), UK.

This study makes use of data generated by the Wellcome Trust Case Control Consortium. A full list of the investigators who contributed to the generation of the data is available on their website (see Web Resources). Funding for the project was provided by the Wellcome Trust under award 076113.

Licence for publication: The Corresponding Author has the right to grant on behalf of all authors and does grant on behalf of all authors, an exclusive licence (or non exclusive for government employees) on a worldwide basis to the BMJ Publishing Group Ltd to permit this article (if accepted) to be published in Journal of Medical Genetics and any other BMJPGL products and sublicences such use and exploit all subsidiary rights, as set out in our licence (http://JMG.bmj.com/misc/ifora/licenceform.shtml).

\section{Web resources:}

Affymetrix: http://www.affymetrix.com/support/technical/index.affx

Almac Diagnostics: www.almacgroup.com/diagnostics/

Corbett Life Science: http://www.corbettlifescience.com/

Database of Genomic Variants: http://projects.tcag.ca/variation/

Decipher: https://decipher.sanger.ac.uk/

Ensembl: http://www.ensembl.org/ 
GENECARDS: http://www.genecards.org/

NCBI: http://www.ncbi.nlm.nih.gov/

BioDiscovery: http://www.biodiscovery.com/

OMIM: http://www.ncbi.nlm.nih.gov/Omim/

Qiagen: www.Qiagen.co.uk/geneglobe

Welcome Trust Case Control Consortium (WTCCC): http://www.wtccc.org.uk/

\section{REFERENCES}

1. Benn PA, Egan JF, Fang M, Smith-Bindman R. Changes in the utilization of prenatal diagnosis. Obstet Gynecol 2004;103:1255-1260

2. Caine A, Maltby AE, Parkin CA, Waters JJ, Crolla JA; UK Association of Clinical Cytogeneticists (ACC). Prenatal detection of Down's syndrome by rapid aneuploidy testing for chromosomes 13, 18, and 21 by FISH or PCR without a full karyotype: a cytogenetic risk assessment. Lancet 2005;366:123128.

3. Shaw-Smith C, Pittman AM, Willatt L, Martin H, Rickman L, Gribble S, Curley R, Cumming S, Dunn C, Kalaitzopoulos D, Porter K, Prigmore E, Krepischi-Santos AC, Varela MC, Koiffmann CP, Lees AJ, Rosenberg C, Firth HV, de Silva R, Carter NP. Microdeletion encompassing MAPT at chromosome $17 \mathrm{q} 21.3$ is associated with developmental delay and learning disability. Nat Genet 2006;38:1032-1037 
4. Koolen DA, Vissers LE, Pfundt R, de Leeuw N, Knight SJ, Regan R, Kooy RF, Reyniers E, Romano C, Fichera M, Schinzel A, Baumer A, Anderlid BM, Schoumans J, Knoers NV, van Kessel AG, Sistermans EA, Veltman JA, Brunner HG, de Vries BB. A new chromosome 17q21.31 microdeletion syndrome associated with a common inversion polymorphism. Nat Genet 2006;38:999-1001

5. Koolen DA, Sharp AJ, Hurst JA, Firth HV, Knight SJ, Goldenberg A, Saugier-Veber P, Pfundt R, Vissers LE, Destrée A, Grisart B, Rooms L, Van der Aa N, Field M, Hackett A, Bell K, Nowaczyk MJ, Mancini GM, Poddighe PJ, Schwartz CE, Rossi E, De Gregori M, Antonacci-Fulton LL, McLellan MD 2nd, Garrett JM, Wiechert MA, Miner TL, Crosby S, Ciccone R, Willatt L, Rauch A, Zenker M, Aradhya S, Manning MA, Strom TM, Wagenstaller J, Krepischi-Santos AC, Vianna-Morgante AM, Rosenberg C, Price SM, Stewart H, Shaw-Smith C, Brunner HG, Wilkie AO, Veltman JA, Zuffardi O, Eichler EE, de Vries BB. Clinical and molecular delineation of the $17 \mathrm{q} 21.31$ microdeletion syndrome. J Med Genet 2008;45:710-720

6. Ben-Shachar S, Ou Z, Shaw CA, Belmont JW, Patel MS, Hummel M, Amato S, Tartaglia N, Berg J, Sutton VR, Lalani SR, Chinault AC, Cheung SW, Lupski JR, Patel A. 22q11.2 distal deletion: a recurrent genomic disorder distinct from DiGeorge syndrome and velocardiofacial syndrome. Am J Hum Genet 2008;82:214-221 
7. Ballif BC, Hornor SA, Jenkins E, Madan-Khetarpal S, Surti U, Jackson KE, Asamoah A, Brock PL, Gowans GC, Conway RL, Graham JM Jr, Medne L, Zackai EH, Shaikh TH, Geoghegan J, Selzer RR, Eis PS, Bejjani BA, Shaffer LG. Discovery of a previously unrecognized microdeletion syndrome of 16p11.2-p12.2. Nat Genet 2007;39:1071-1073

8. Rajcan-Separovic E, Harvard C, Liu X, McGillivray B, Hall JG, Qiao Y, Hurlburt J, Hildebrand J, Mickelson EC, Holden JJ, Lewis ME. Clinical and molecular cytogenetic characterisation of a newly recognised microdeletion syndrome involving 2p15-16.1. J Med Genet 2007;44:269-276

9. McCarroll SA, Hadnott TN, Perry GH, Sabeti PC, Zody MC, Barrett JC, Dallaire S, Gabriel SB, Lee C, Daly MJ, Altshuler DM; International HapMap Consortium. Common deletion polymorphisms in the human genome. Nat Genet 2006;38:86-92.

10. Sharp AJ, Locke DP, McGrath SD, Cheng Z, Bailey JA, Vallente RU, Pertz LM, Clark RA, Schwartz S, Segraves R, Oseroff VV, Albertson DG, Pinkel D, Eichler EE. Segmental duplications and copy-number variation in the human genome. Am J Hum Genet 2005;77:78-88

11. de Smith AJ, Tsalenko A, Sampas N, Scheffer A, Yamada NA, Tsang P, BenDor A, Yakhini Z, Ellis RJ, Bruhn L, Laderman S, Froguel P, Blakemore AI. Array CGH analysis of copy number variation identifies 1284 new genes 
variant in healthy white males: implications for association studies of complex diseases. Hum Mol Genet 2007;16:2783-2794

12. Wang K, Li M, Hadley D, Liu R, Glessner J, Grant SF, Hakonarson H, Bucan, M. PennCNV: an integrated hidden Markov model designed for highresolution copy number variation detection in whole-genome SNP genotyping data. Genome Res 2007;17:1665-1674

13. Lee C, Iafrate AJ, Brothman AR. Copy number variations and clinical cytogenetic diagnosis of constitutional disorders. Nat Genet 2007;39:S48-54

14. McCarroll SA, Kuruvilla FG, Korn JM, Cawley S, Nemesh J, Wysoker A, Shapero MH, de Bakker PI, Maller JB, Kirby A, Elliott AL, Parkin M, Hubbell E, Webster T, Mei R, Veitch J, Collins PJ, Handsaker R, Lincoln S, Nizzari M, Blume J, Jones KW, Rava R, Daly MJ, Gabriel SB, Altshuler D. Integrated detection and population-genetic analysis of SNPs and copy number variation. Nat Genet 2008;40:1166-1174

15. WTCCC. Genome-wide association study of 14,000 cases of seven common diseases and 3,000 shared controls. Nature 2007;447:661-678

16. Rauch A, Zink S, Zweier C, Thiel CT, Koch A, Rauch R, Lascorz J, Hüffmeier U, Weyand M, Singer H, Hofbeck M. Systematic assessment of atypical deletions reveals genotype-phenotype correlation in 22q11.2. J Med Genet 2005;42:871-876 
17. Kurahashi H, Nakayama T, Osugi Y, Tsuda E, Masuno M, Imaizumi K, Kamiya T, Sano T, Okada S, Nishisho I. Deletion mapping of 22q11 in CATCH22 syndrome: identification of a second critical region. Am J Hum Genet 1996;58:1377-1381

18. Garcia-Miñaur S, Fantes J, Murray RS, Porteous ME, Strain L, Burns JE, Stephen J, Warner JP. A novel atypical 22q11.2 distal deletion in father and son. J Med Genet 2002;39:E62

19. Xu J, Fun YS, Siu VM. A child with features of Goldenhar syndrome and a novel $1.12 \mathrm{Mb}$ deletion in $22 \mathrm{q} 11.2$ by cytogenetics and oligonucleotide array $\mathrm{CGH}$ : is this a candidate region for the syndrome? Am J Med Genet A 2008;146A:1886-1889

20. Klaassens M, Galjaard RJ, Scott DA, Brüggenwirth HT, van Opstal D, Fox MV, Higgins RR, Cohen-Overbeek TE, Schoonderwaldt EM, Lee B, Tibboel D, de Klein A. Prenatal detection and outcome of congenital diaphragmatic hernia $(\mathrm{CDH})$ associated with deletion of chromosome 15q26: two patients and review of the literature. Am J Med Genet A 2007;143A:2204-2212

21. Lurie IW. Kidney abnormalities in persons with monosomy 15q26. Am J Med Genet A 2008;146A:1761-1764 
22. Pereira FA, Qiu Y, Zhou G, Tsai M-J, Tsai SY. The orphan nuclear receptor COUP-TFII is required for angiogenesis and heart development. Genes Dev 1999;13:1037-1049

23. Pober BR. Genetic aspects of human congenital diaphragmatic hernia. Clin Genet 2008;74:1-15

24. Holden ST, Cox JJ, Kesterton I, Thomas NS, Carr C, Woods CG. Fanconi anaemia complementation group B presenting as X linked VACTERL with hydrocephalus syndrome. J Med Genet 2006;43:750-754

25. Cotter PD, McCurdy LD, Gershin IF, Babu A, Willner JP, Desnick RJ. Prenatal detection and molecular characterization of a de novo duplication of the distal long arm of chromosome 19. Am J Med Genet 1997;71:325-328

26. Mefford HC, Sharp AJ, Baker C, Itsara A, Jiang Z, Buysse K, Huang S, Maloney VK, Crolla JA, Baralle D, Collins A, Mercer C, Norga K, de Ravel T, Devriendt K, Bongers EM, de Leeuw N, Reardon W, Gimelli S, Bena F, Hennekam RC, Male A, Gaunt L, Clayton-Smith J, Simonic I, Park SM, Mehta SG, Nik-Zainal S, Woods CG, Firth HV, Parkin G, Fichera M, Reitano S, Giudice ML, Li KE, Casuga I, Broomer A, Conrad B, Schwerzmann M, Räber L, Gallati S, Striano P, Coppola A, Tolmie JL, Tobias ES, Lilley C, Armengol L, Spysschaert Y, Verloo P, De Coene A, Goossens L, Mortier G, Speleman F, van Binsbergen E, Nelen MR, Hochstenbach R, Poot M, Gallagher L, Gill M, McClellan J, King MC, Regan R, Skinner C, Stevenson 
RE, Antonarakis SE, Chen C, Estivill X, Menten B, Gimelli G, Gribble S, Schwartz S, Sutcliffe JS, Walsh T, Knight SJ, Sebat J, Romano C, Schwartz CE, Veltman JA, de Vries BB, Vermeesch JR, Barber JC, Willatt L, Tassabehji M, Eichler EE. Recurrent Rearrangements of Chromosome 1q21.1 and Variable Pediatric Phenotypes. N Engl J Med 2008;359:1685-1699

27. Brunetti-Pierri N, Berg JS, Scaglia F, Belmont J, Bacino CA, Sahoo T, Lalani SR, Graham B, Lee B, Shinawi M, Shen J, Kang SH, Pursley A, Lotze T, Kennedy G, Lansky-Shafer S, Weaver C, Roeder ER, Grebe TA, Arnold GL, Hutchison T, Reimschisel T, Amato S, Geragthy MT, Innis JW, Obersztyn E, Nowakowska B, Rosengren SS, Bader PI, Grange DK, Naqvi S, Garnica AD, Bernes SM, Fong CT, Summers A, Walters WD, Lupski JR, Stankiewicz P, Cheung SW, Patel A. Recurrent reciprocal 1q21.1 deletions and duplications associated with microcephaly or macrocephaly and developmental and behavioral abnormalities. Nat Genet 2008;40:1466-1471

28. Sonek J. First trimester ultrasonography in screening and detection of fetal anomalies. Am J Med Genet 2007;145C:45-61

29. Knight MA, Kennerson ML, Anney RJ, Matsuura T, Nicholson GA, SalimiTari P, Gardner RJM, Storey E, Forrest SM. Spinocerebellar ataxia type 15 (SCA15) maps to 3p24.2-3pter: exclusion of the ITPR1 gene, the human orthologue of an ataxic mouse mutant. Neurobiol Dis 2003;13:147-157 
30. Iwaki A, Kawano Y, Miura S, Shibata H, Matsuse D, Li W, Furuya H, Ohyagi Y, Taniwaki T, Kira J, Fukumaki Y. Heterozygous deletion of ITPR1, but not SUMF1, in spinocerebellar ataxia type 16. J Med Genet 2008;45:32-35

31. Barber JC. Terminal 3p deletions: phenotypic variability, chromosomal nonpenetrance, or gene modification? Am J Med Genet A 2008;146A:1899-1901

32. Malmgren H, Sahlén S, Wide K, Lundvall M, Blennow E. Distal 3p deletion syndrome: detailed molecular cytogenetic and clinical characterisation of three small distal deletions and review. Am J Med Genet A 2007;146A:2143-2149

33. Griggs BL, Ladd S, Saul RA, DuPont BR, Srivastava AK. Dedicator of cytokinesis 8 is disrupted in two patients with mental retardation and developmental disabilities. Genomics 2008;91:195-202

34. Lerer I, Sagi M, Meiner V, Cohen T, Zlotogora J, Abeliovich D. Deletion of the ANKRD15 gene at 9p24.3 causes parent-of-origin-dependent inheritance of familial cerebral palsy. Hum Mol Genet 2005;14:3911-3920

35. Farrell SA, Sue-Chue-Lam A, Miskin M, Yao-Shan Fan. Fetal nuchal oedema and antenatal diagnosis of trisomy 10. Prenatal Diagnosis 1994;14:463-467

36. Woods CG, Cox J, Springell K, Hampshire DJ, Mohamed MD, McKibbin M, Stern R, Raymond LR, Sandford R, Malik-Sharif S, Karbani G, Ahmed M, Bond J, Clayton D, Inglehearn CF. Quantifications of homozygosity in 
consanguineous individuals with autosomal recessive disease. Am J Hum Genet 2006;78:889-896

37. Shaffer LG, Coppinger J, Alliman S, Torchia BA, Theisen A, Ballif BC, Bejjani BA. Comparison of microarray-based detection rates for cytogenetic abnormalities in prenatal and neonatal specimens. Prenat Diagn 2008;28:789795

38. Le Caignec C, Boceno M, Saugier-Veber P, Jacquemont S, Joubert M, David A, Frebourg T, Rival JM. Detection of genomic imbalances by array based comparative genomic hybridisation in fetuses with multiple malformations. $J$ Med Genet 2005;42:121-128

39. Stankiewicz P, Beaudet AL. Use of array CGH in the evaluation of dysmorphology, malformations, developmental delay, and idiopathic mental retardation. Curr Opin Genet Dev 2007;17:182-192

40. Manning M, Hudgins L. Use of array-based technology in the practice of medical genetics. Genet Med 2007;9:650-653

41. Zahir F, Friedman JM. The impact of array genomic hybridization on mental retardation research: a review of current technologies and their clinical utility. Clin Genet 2007;72:271-287 
42. Palomares Bralo M, Delicado A, Lapunzina P, Valázquez R, Villa O, Ángeles Mori M, de Torres ML, Fernández L, Pérez Jurado LA, López Pajares I. Direct tandem duplication in chromosome $19 \mathrm{q}$ characterized by array CGH. Eur J Med Genet 2008;51:257-263

43. Bruno DL, Ganesamoorthy D, Schoumans J, Bankier A, Coman D, Delatycki M, Gardner MR, Hunter M, James PA, Kannu P, McGillivray G, Pachter N, Peters H, Rieubland C, Savarirayan R, Scheffer IE, Sheffield L, Tan T, White SM, Yeung A, Bowman Z, Ngo C, Choy K, Cacheux V, Wong L, Amor D, Slater HR. Detection of Cryptic Pathogenic Copy Number Variations and Constitutional Loss of Heterozygosity using High Resolution SNP Microarray Analysis in 117 Patients Referred for Cytogenetic Analysis and Impact on Clinical Practice. J Med Genet 2008;Nov 17:[Epub ahead of print]

44. Rosenberg C, Knijnenburg J, Bakker E, Vianna-Morgante AM, Sloos W, Otto PA, Kriek M, Hansson K, Krepischi-Santos AC, Fiegler H, Carter NP, Bijlsma EK, van Haeringen A, Szuhai K, Tanke HJ. Array-CGH detection of micro rearrangements in mentally retarded individuals: clinical significance of imbalances present both in affected children and normal parents. J Med Genet 2006;43:180-186

45. de Ravel TJ, Balikova I, Thienpont B, Hannes F, Maas N, Fryns JP, Devriendt K, Vermeesch JR. Molecular karyotyping of patients with MCA/MR: the blurred boundary between normal and pathogenic variation. Cytogenet Genome Res 2006;115:225-230 
46. Bisgaard AM, Kirchhoff M, Nielsen JE, Brandt C, Hove H, Jepsen B, Jensen T, Ullmann R, Skovby F. Transmitted cytogenetic abnormalities in patients with mental retardation: pathogenic or normal variants? Eur J Med Genet 2007;50:243-255 


\section{Figure Legends}

Figure 1 Nexus plots of SNP 6.0 data showing deletions and duplications in the 10 likely pathogenic copy number variations (CNVs) from table 1. Calling threshold changes are shown along the $y$-axis, where green lines indicate duplications and red lines indicate deletions. Location in $\mathrm{Mb}$ is provided along the $x$-axis. Panel $(A)$ shows whole chromosome plots for the CNVs greater than $1 \mathrm{Mb}$ and panel $(\mathrm{B})$ shows zoomed in views for the CNVs of less than $1 \mathrm{Mb}$ in size.

Figure 2 Large likely pathogenic CNVs ( $>500 \mathrm{~kb})$ confirmed by FISH. A and B: 19p13.2 duplication CNV in interphase nucleus (A) and partial metaphase (B). The BAC clone RP11-109L17 clone labelled in spectrum red shows 3 signals in the nucleus and an enlarged signal on one chromosome 19 in metaphase. The control clone RP11-384 (spectrum green) maps to 19q13.42. 16q24.1 deletion CNV in partial metaphase confirmed with RP1156511 probe in spectrum green (no signal on one chromosome 16), and control probe RP11-368N21 (spectrum red) that maps to (16p12) (C). 19q13.42 deletion confirmed by RP11-384G4 clone (spectrum green), control probe RP11-109L17 (spectrum red) maps to chromosome 19p13.2) (D).

Figure 3 Rare CNVs of unknown clinical significance from table 3. Nexus plots of SNP 6.0 data showing deletions and duplications in 12 patients. Calling threshold changes along y-axis, where green lines indicate duplications and red lines indicate deletions. Size in Mb is provided along the 
x-axis. Panel (A) shows zoomed in views of deletions and panel (B) zoomed in views of duplications.

Figure 4 'Allele Difference' plots in Genotyping Console v2.1 showing the identification of trisomy 10 mosaicism and triploidy $(A, B)$ and $\mathrm{LOH}(\mathrm{C})$. Part of chromosome 10 is shown in A and part of chromosome 11 in $B$ for the mosaic trisomy 10 (violet), triploid (blue) and a normal (orange) sample. For the mosaic trisomy 10 sample the abnormal allele difference pattern is observed for chromosome $10(\mathrm{~A})$ and is not present for chromosome $11(\mathrm{~B})$. For the triploid sample both chromosomes 10 and 11 show an abnormal allele difference pattern (in panels A and B). In panel (C), the 'Allele Difference' plot is shown for chromosome 18. This sample shows a lack of heterozygous calls (row 1), which is further illustrated in the $\mathrm{LOH}$ plot (row 2). The same reference sample as in $A$ and $B$ (orange) illustrates the normal heterozygosity pattern for this chromosome (row 3) and absence of LOH calls (row 4).

Figure 5 Genes of interest are expressed. Rotor-Gene software plots show PXMP3 indicated in bright green (A), STK3 indicated in violet (B), LPHN3 indicated in light blue (C) and PTPN13 indicated in violet (D). Four controls were used, indicated in orange, salmon, yellow and purple (A and B). Three controls were used, indicated in orange, salmon and yellow (C and D). 


\section{Figure 1/panel A}

A

$\operatorname{del}(15)(q 26.2 q 26.2)$

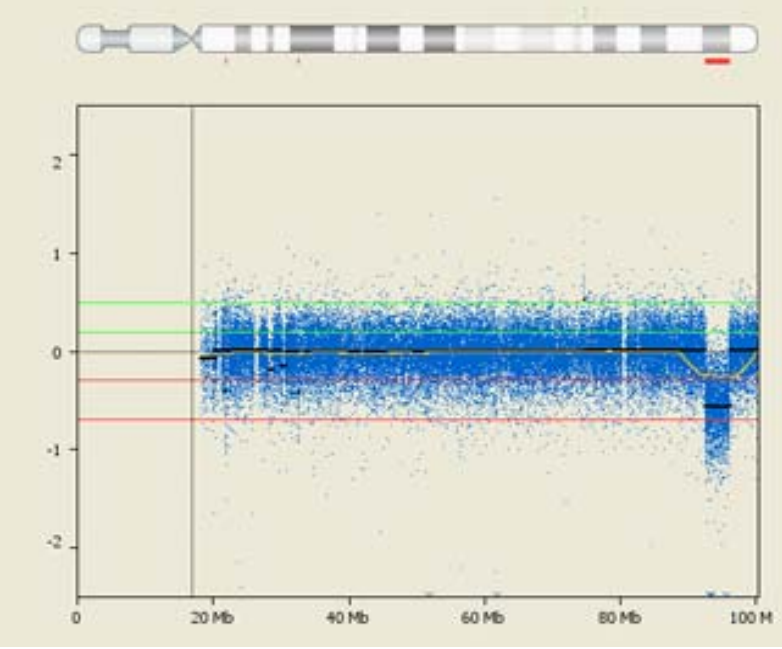

$\operatorname{del}(19)(q 13.42 q 13.42)$

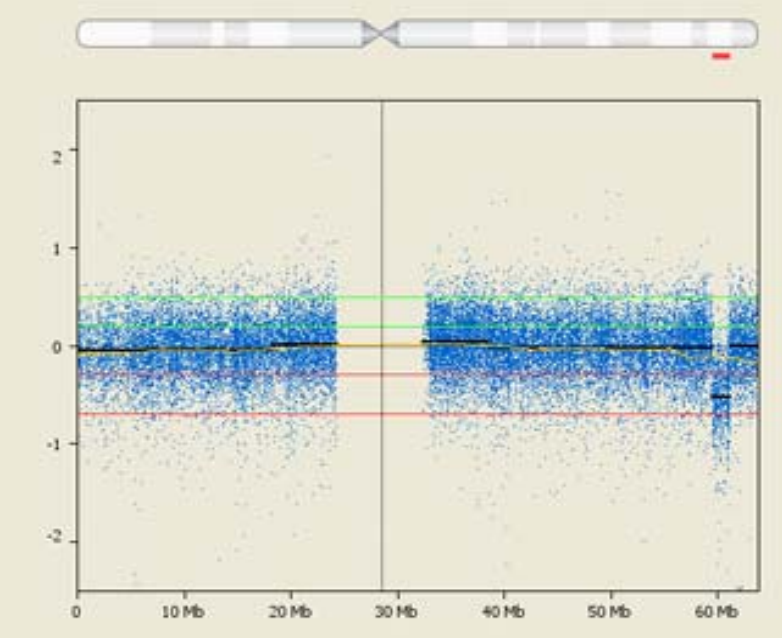

del(16)(q24.1q24.2)

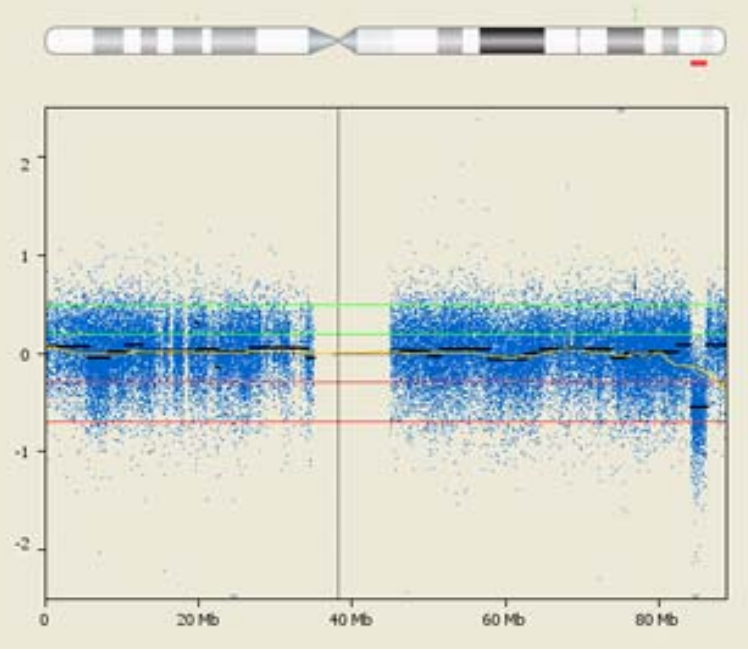

$\operatorname{del}(22)(q 11.21 q 11.22)$

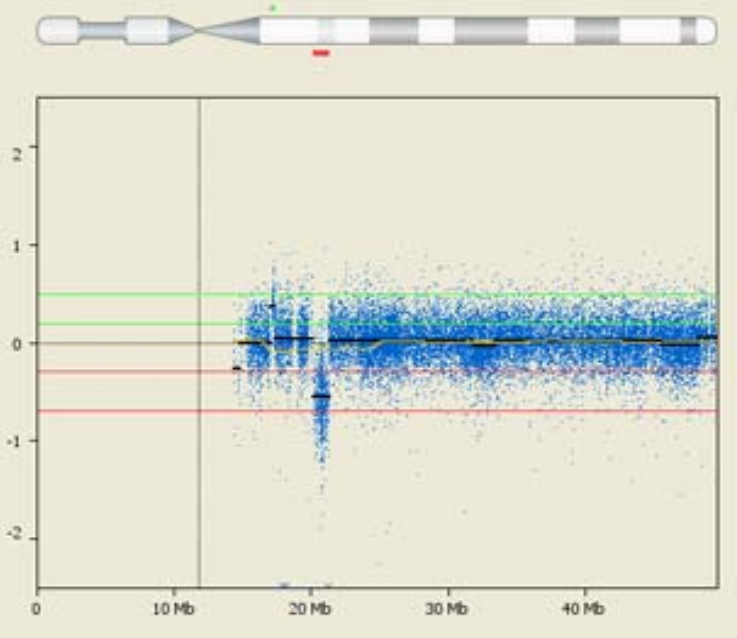

$\operatorname{dup}(19)(p 13.2 p 13.2)$

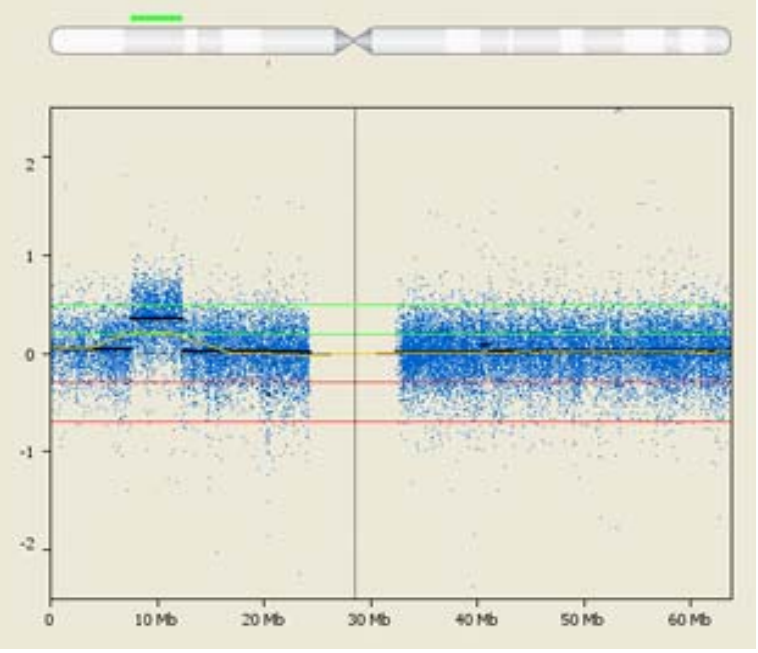




\section{Figure 1/panel B}

B

$\operatorname{dup}(15)(q 21.1 \mathrm{q} 21.1)$

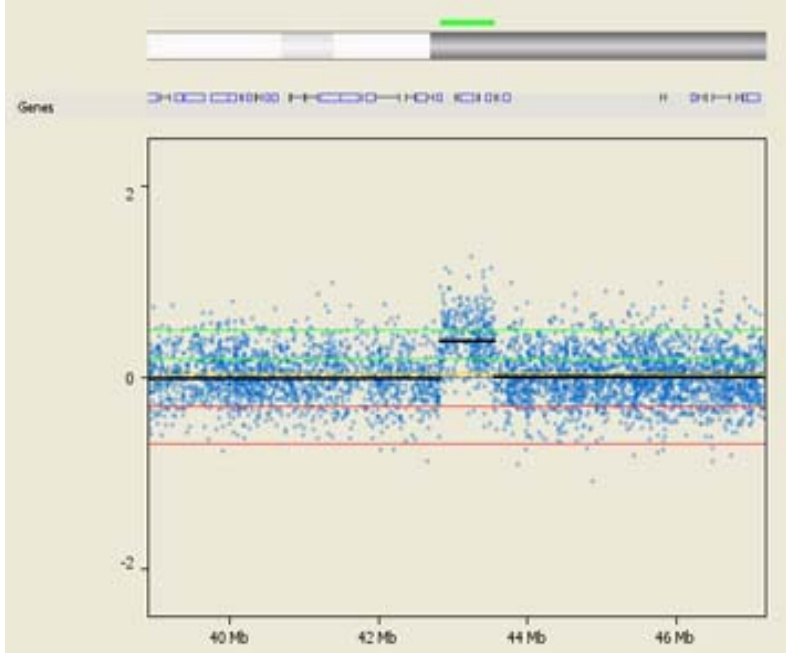

$\operatorname{del}(22)(q 11.21 q 11.21)$

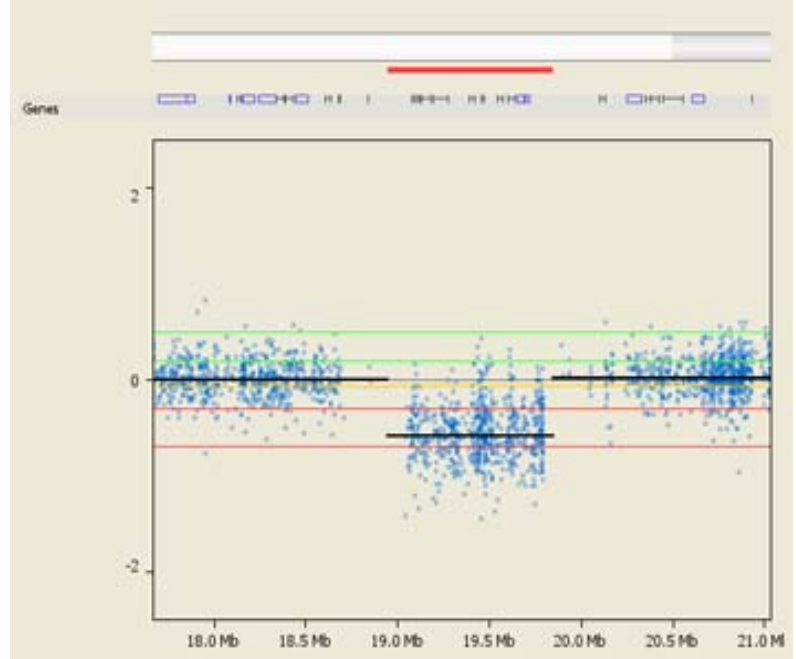

$\operatorname{del}(17)(q 21.31 q 21.31)$

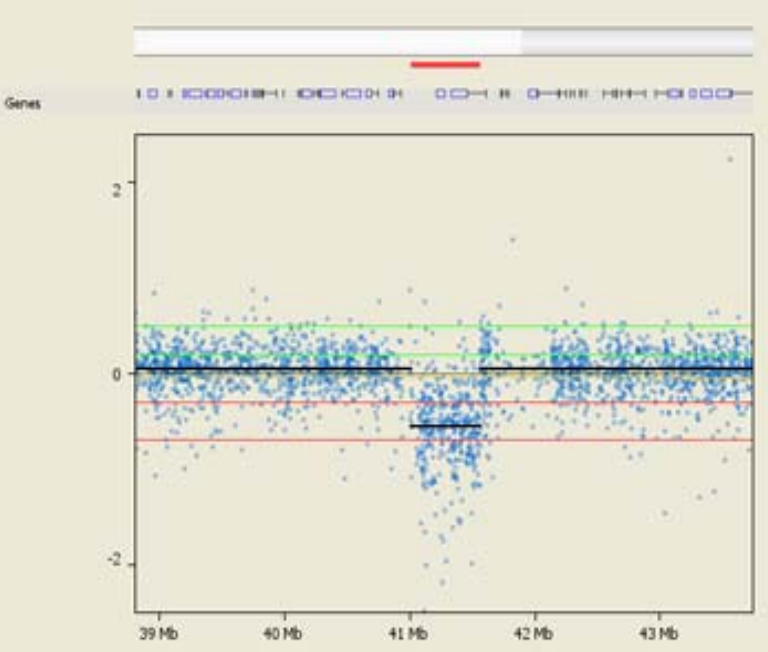

$\operatorname{del}(X)(p 22.2 p 22.2)$

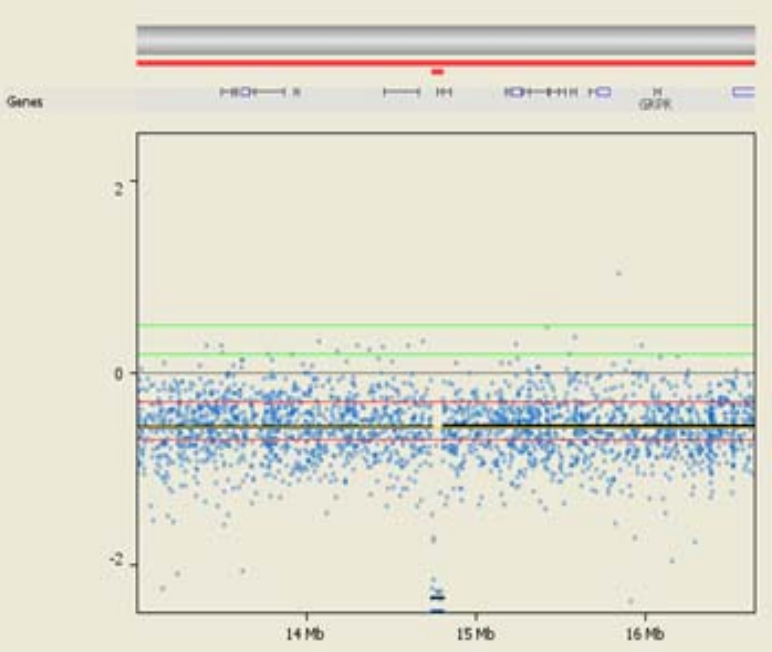

$\operatorname{dup}(19)(q 13.41 q 13.42)$

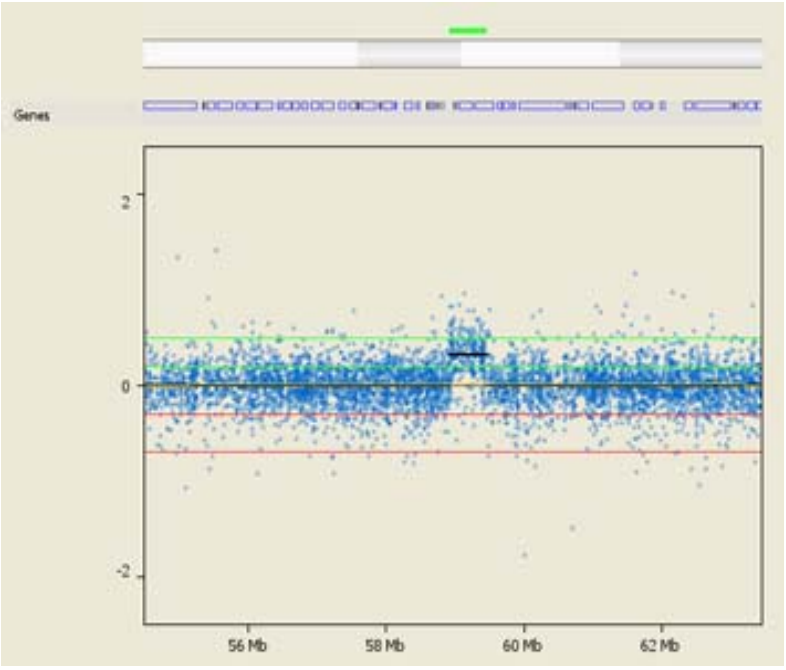


Figure 2

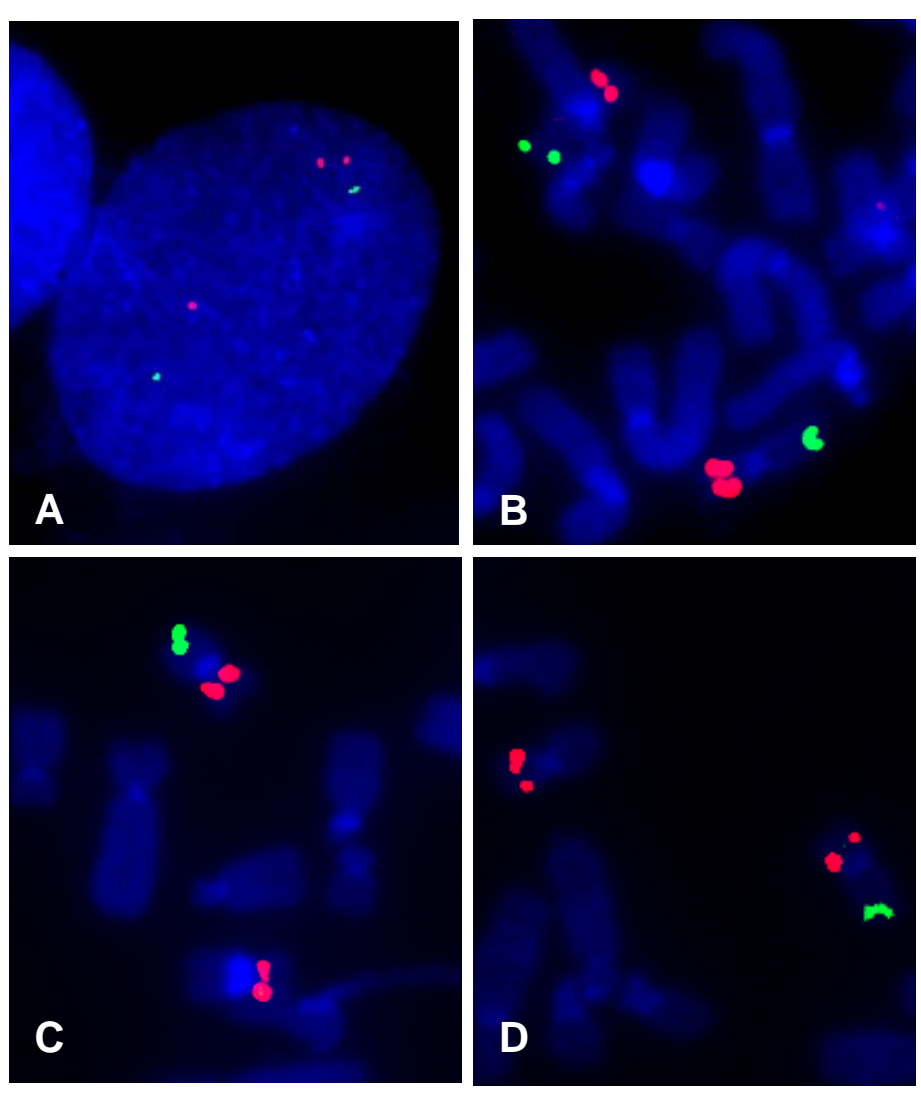




\section{Figure 3/panel A}

A

del(3)(p26.2p26.2)

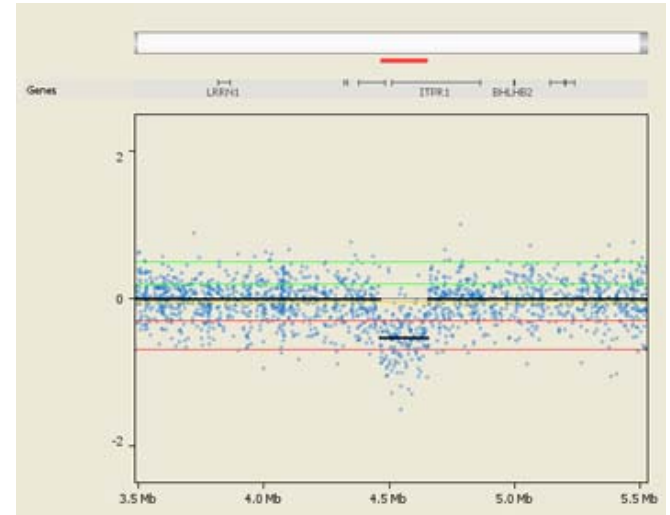

del(8)(q22.2q22.2)

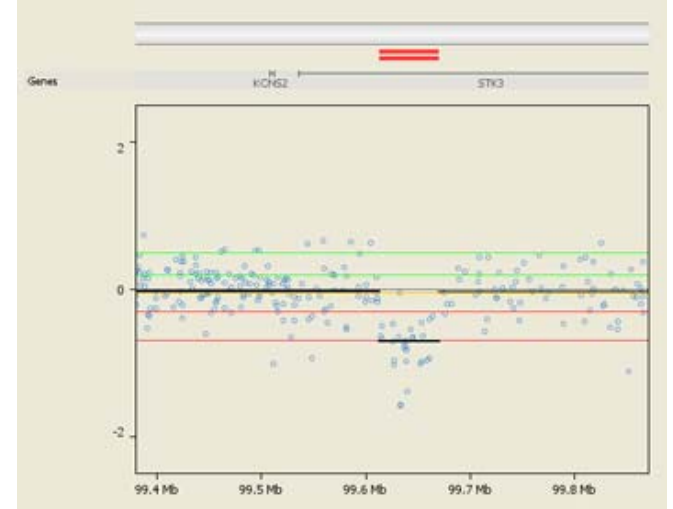

$\operatorname{del}(4)(q 13.1 q 13.1)$

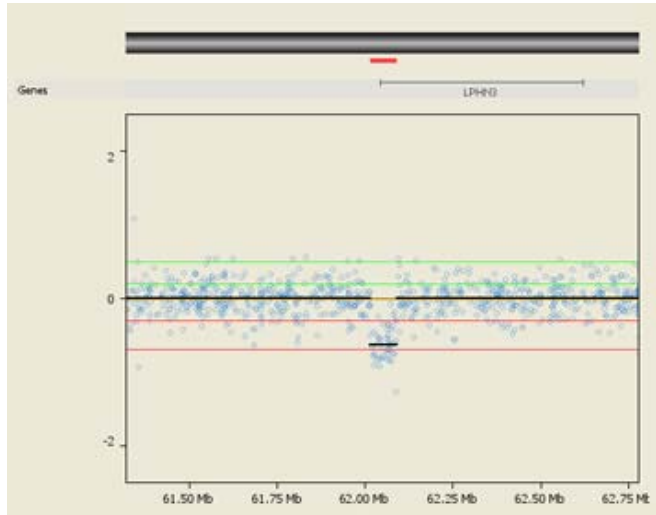

$\operatorname{del}(13)(q 21.2 q 21.2)$

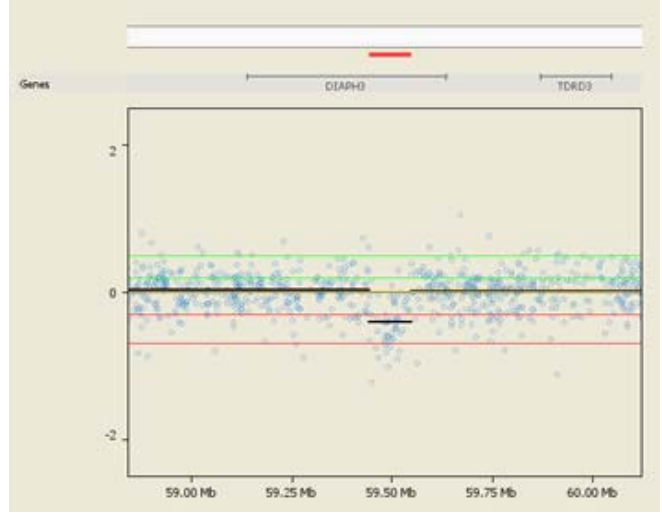

del(8)(q21.11q21.11)

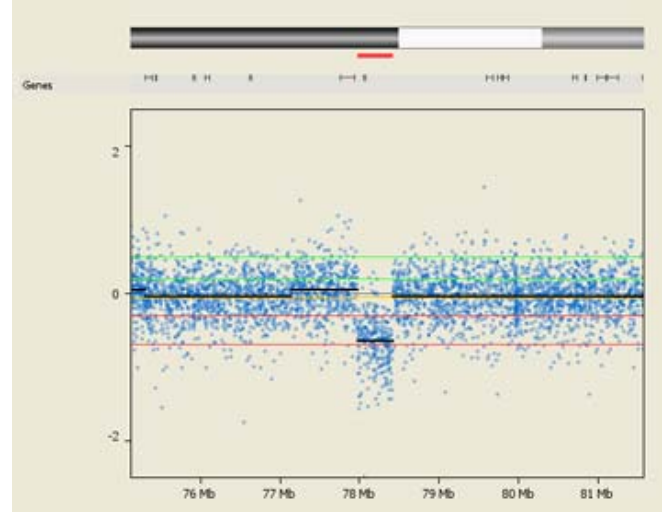

$\operatorname{del}(X)(q 24 q 24)$

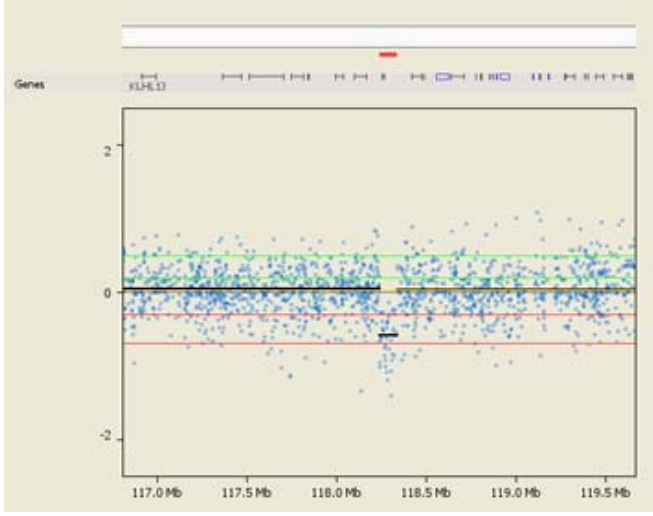


Figure 3/ panel B
B $\quad \operatorname{dup}(2)(q 11.2 q 11.2)$

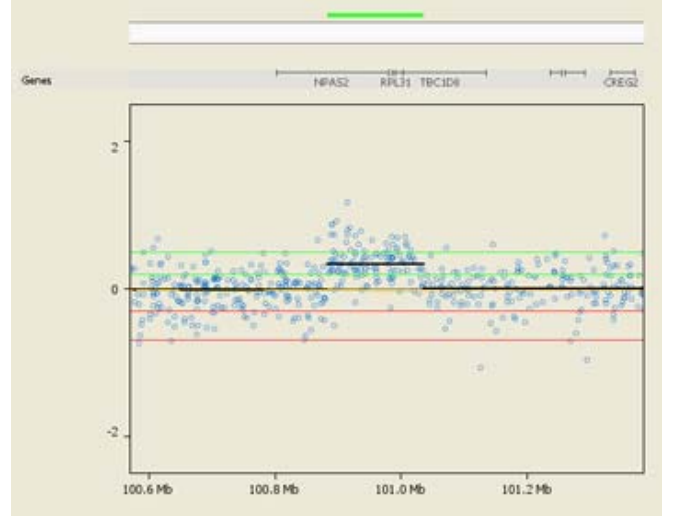

$\operatorname{dup}(13)(q 12.3 q 12.3)$

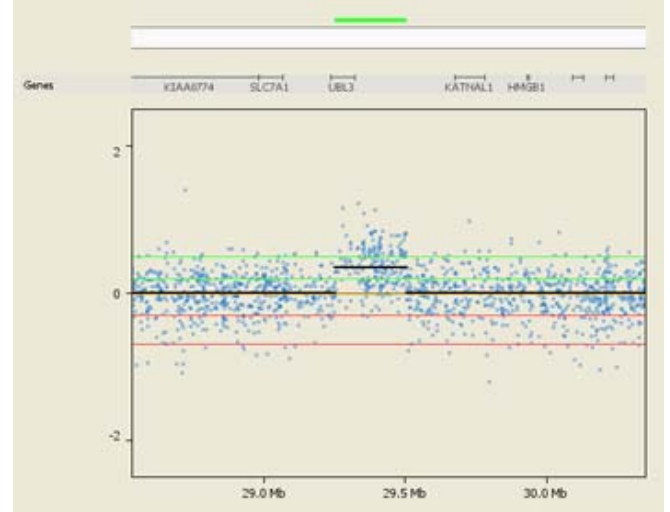

$\operatorname{dup}(X)(p 22.12 p 22.12)$

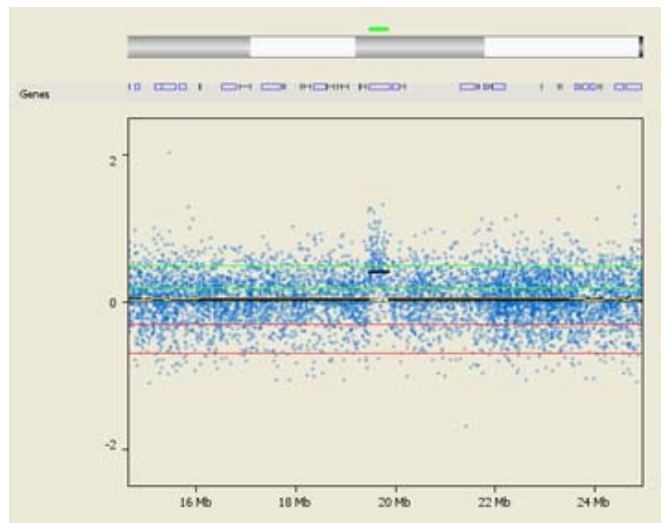

$\operatorname{dup}(9)(p 24.3 p 24.3)$

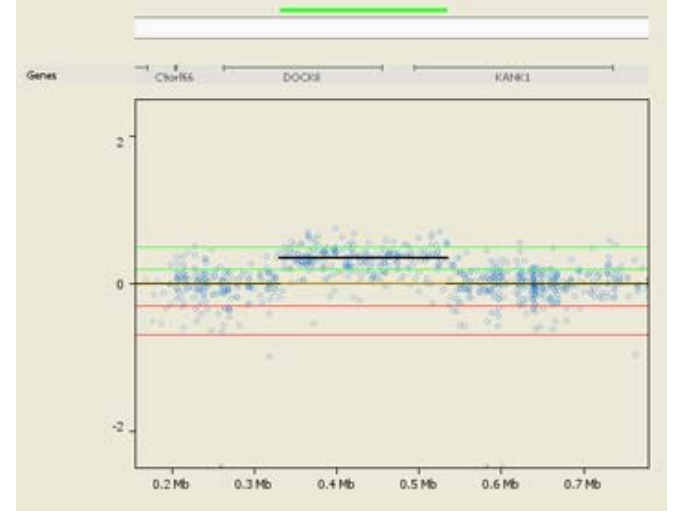

dup(15)(q21.1q21.1)

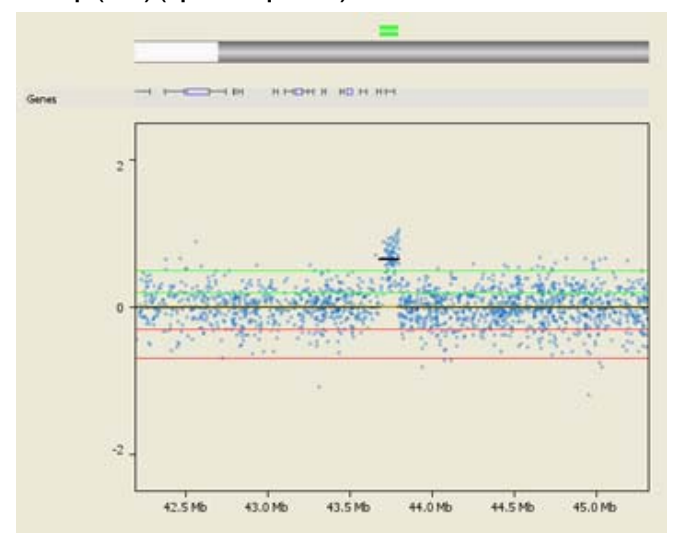

$\operatorname{dup}(12)(q 14.1 q 14.1)$

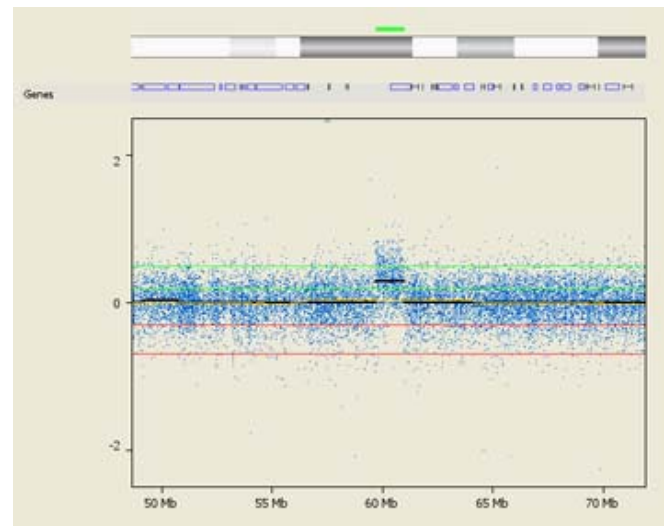

dup(16)(p13.2p13.2)

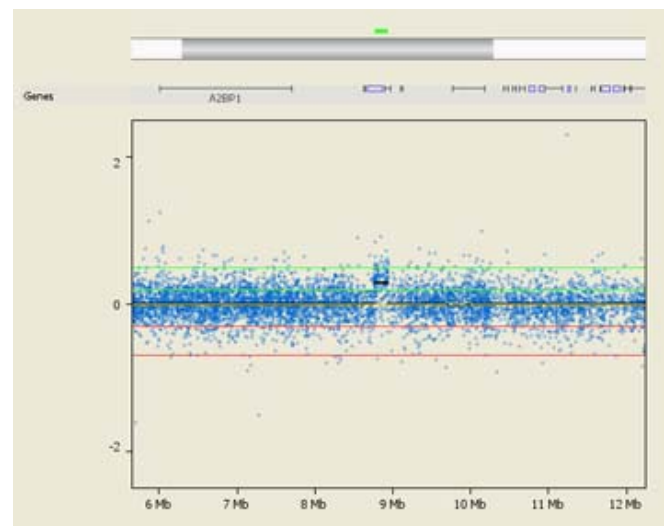




\section{Figure 4}

A

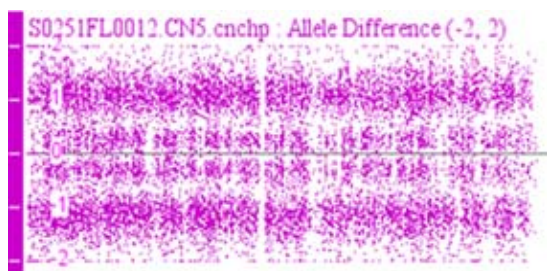

S035SFL0032. CNS cnchp : Allete Difference $(-2,2)$

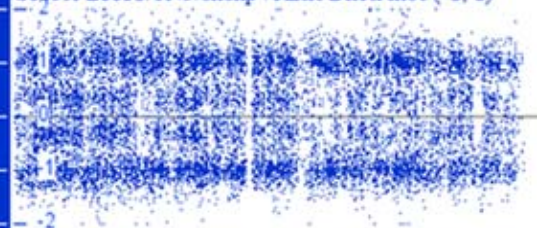

S0287FL0003 CNNS cnchp Allete Difference $(-2,2)$

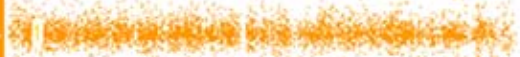

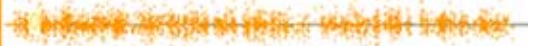

1
B

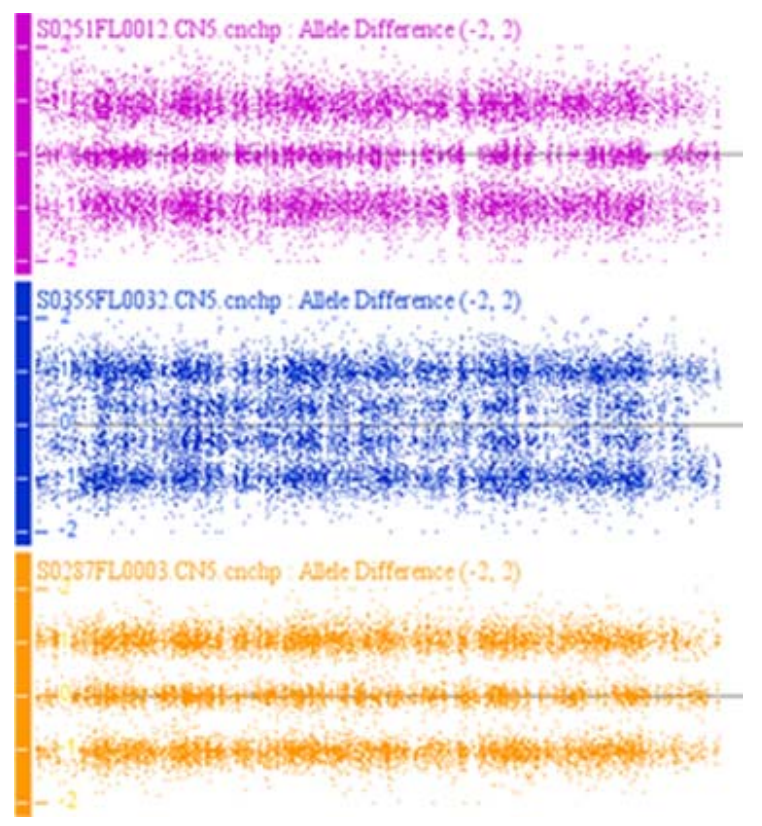

C

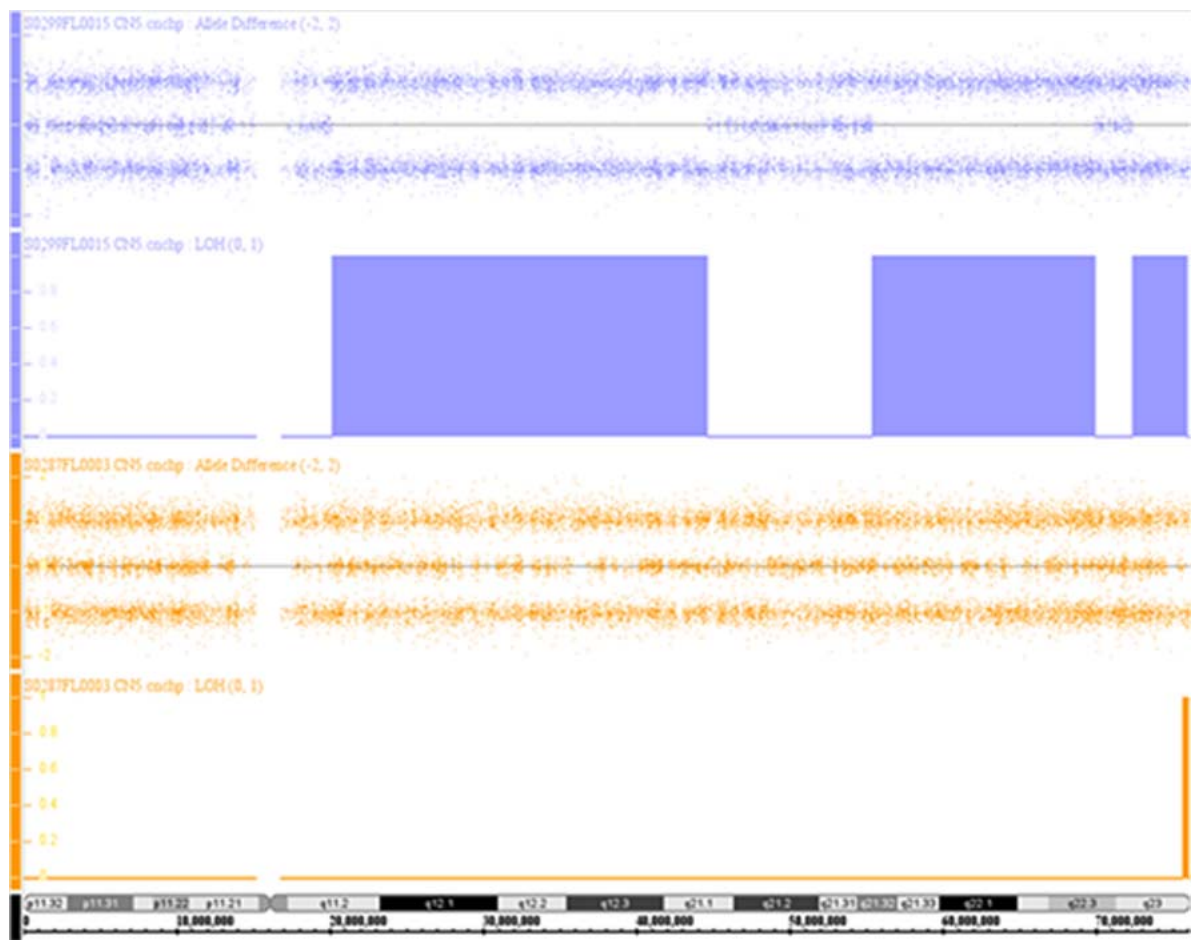


Figure 5

A

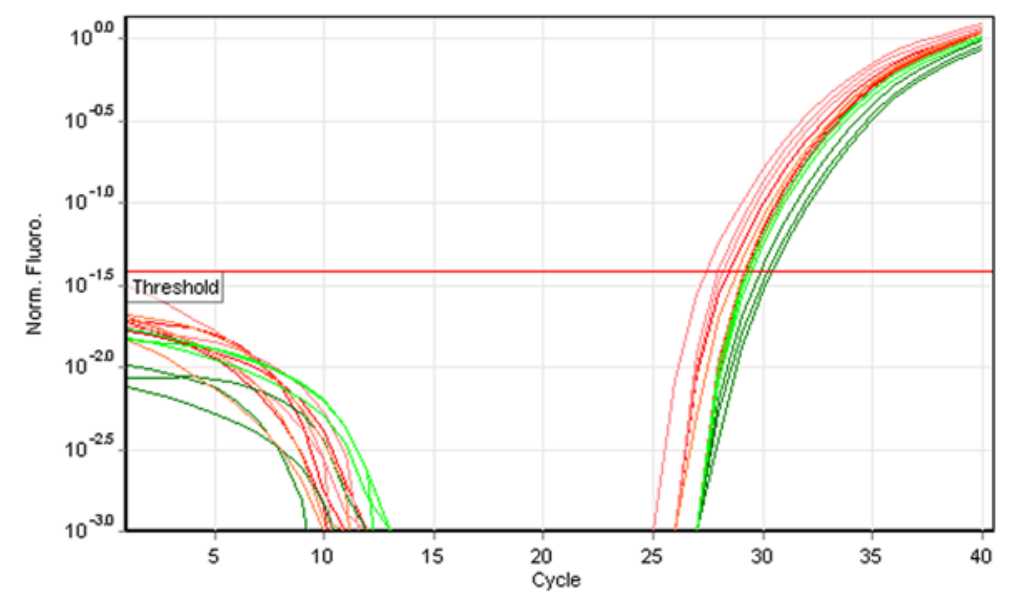

C

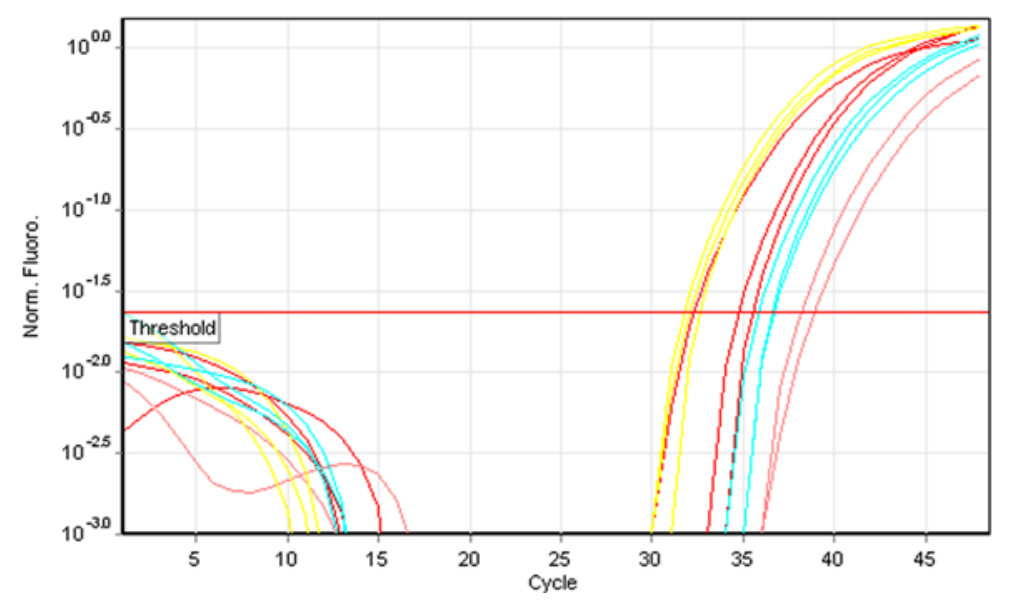

B

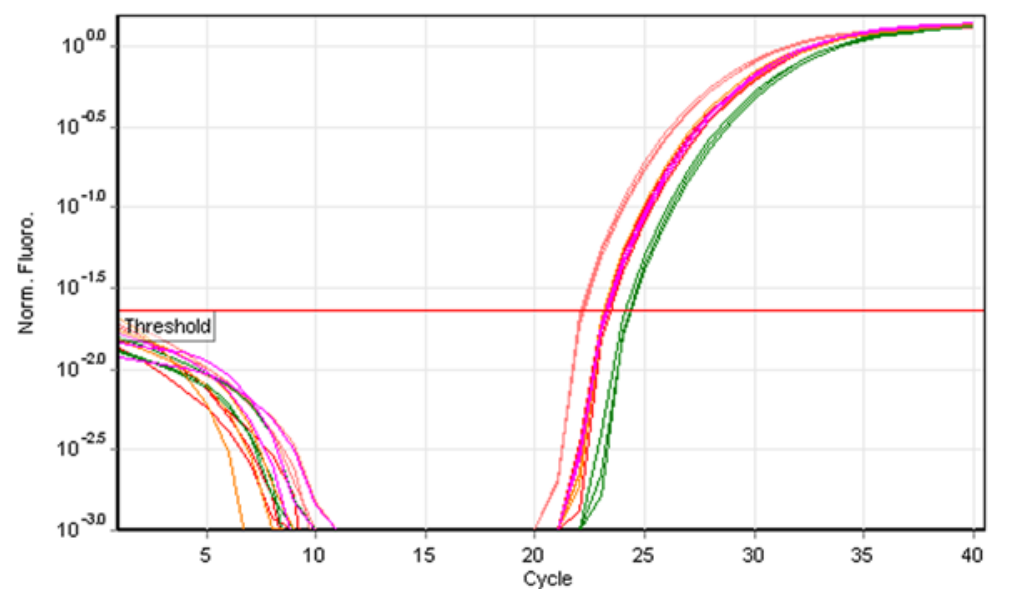

D

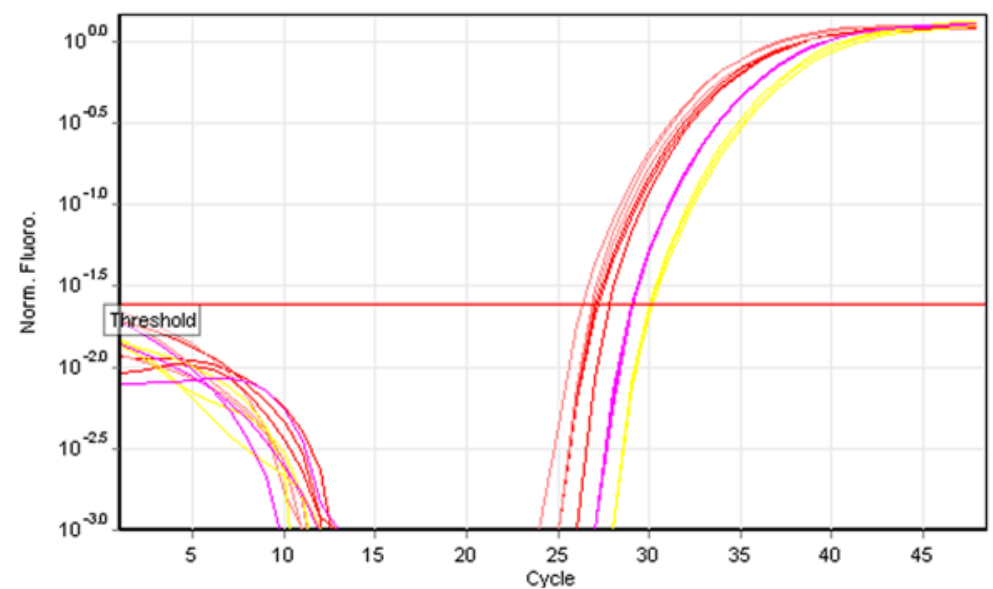

